Mark Lang

Kenan-Flagler Business School University of North Carolina

\title{
Employee Stock Options and Equity Valuation
}

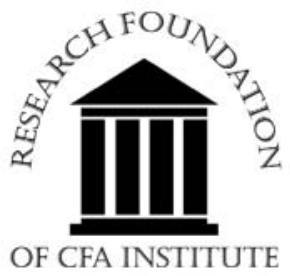


The Research Foundation of CFA Institute and the Research Foundation logo are trademarks owned by The Research Foundation of CFA Institute. CFA ${ }^{\circledR}$, Chartered Financial Analyst ${ }^{\circledR}$, AIMR-PPS ${ }^{\circledR}$, and GIPS ${ }^{\circledR}$ are just a few of the trademarks owned by CFA Institute. To view a list of CFA Institute trademarks and a Guide for the Use of CFA Institute Marks, please visit our website at www.cfainstitute.org.

(C) 2004 The Research Foundation of CFA Institute

All rights reserved. No part of this publication may be reproduced, stored in a retrieval system, or transmitted, in any form or by any means, electronic, mechanical, photocopying, recording, or otherwise, without the prior written permission of the copyright holder.

This publication is designed to provide accurate and authoritative information in regard to the subject matter covered. It is sold with the understanding that the publisher is not engaged in rendering legal, accounting, or other professional service. If legal advice or other expert assistance is required, the services of a competent professional should be sought.

ISBN 0-943205-67-0

Printed in the United States of America

July 2, 2004

\author{
Editorial Staff \\ Maryann Dupes \\ Book Editor
}

Christine E. Kemper

Kara H. Morris

Assistant Editor

Production Manager

Lois A. Carrier/Jesse Kochis

Composition and Production 


\section{Mission}

The Research Foundation's mission is to encourage education for investment practitioners worldwide and to fund, publish, and distribute relevant research. 


\section{Biography}

Mark Lang is Thomas W. Hudson, Jr./Deloitte and Touche L.L.P. Distinguished Professor at the Kenan-Flagler Business School at the University of North Carolina. Professor Lang's research interests include stock market valuation of accounting information; international accounting and analysis; employee stock option valuation, taxation, and exercise behavior; causes and effects of voluntary disclosure; and multinational tax strategy. His research on stock options has been published in the Journal of Finance, Quarterly Journal of Economics, and Journal of Accounting and Economics. He has served on the International Accounting Standards Board's Share-Based Payment Advisory Group and the American Institute of CPAs Blockage Factor Task Force. Professor Lang holds a BS from Sioux Falls College and an MBA and a PhD from the University of Chicago. 


\section{Contents}

Foreword $\ldots \ldots \ldots \ldots \ldots \ldots \ldots \ldots \ldots \ldots \ldots$, vi

Preface $\ldots \ldots \ldots \ldots \ldots \ldots \ldots \ldots \ldots \ldots \ldots \ldots \ldots$, viii

Chapter 1. Employee Stock Option Basics ............ 1

Chapter 2. Expected Cost of Options............... 7

Chapter 3. Patterns of Option Exercise............... 25

Chapter 4. Option Value to Employees .............. 40

Chapter 5. Impact on Cash Flow and Valuation .......... 46

Chapter $6 . \quad$ Summary and Application . ............. 56

Appendix ............................... 62

References................................ 69 


\section{Foreword}

One of the great challenges of corporate management is to align the interests of employees and shareholders, and increasingly, companies are resorting to employee stock options to meet this challenge. Stock options grant employees a direct stake in the fortunes of the company; hence, employees are motivated to engage in value-enhancing behavior, which benefits shareholders. This apparent simplicity in logic, however, belies a considerable amount of complexity in the implementation and valuation of employee stock options.

Mark Lang addresses the key issues of employee stock options primarily from the perspective of an analyst charged with valuing a company, although he views these issues from the perspective of employees as well. He begins with a description of a typical employee stock option and measures the claim it poses against shareholders. Lang then discusses the accounting issues surrounding employee stock options. He leaves no doubt as to the importance of these claims, noting that in 2000, tax deductions for options exceeded net income for 8 of the largest 100 companies in the S\&P 100 Index and, on average, for all companies in the NASDAQ 100 Index.

Lang then reviews the features of employee stock options that differentiate them from traded options. Because employees are typically prohibited from hedging these options by selling stock against them, early exercise is common, which means it is important to determine patterns of exercise in order to value them properly. Lang reviews the empirical literature, much of which he contributed to, about exercise patterns. He notes that as the ratio of the market price to the strike price rises, early exercise increases. But as the options approach their expiration dates, employees will exercise at lower ratios. Employees also tend to exercise as volatility rises (because they are risk averse) and soon after vesting (because demand for liquidity builds up during the prevesting date). One of Lang's most interesting observations is that subsequent company returns are inversely correlated with the incidence of exercise, suggesting that company insiders have privileged information about the prospects for the company.

Lang discusses the prevalent methods for valuing employee stock options. Many companies modify the Black-Scholes valuation model by assuming that exercise occurs halfway to expiration. This assumption, however, usually overvalues options compared with a more realistic assumption that exercise occurs throughout the term to expiration. A more significant bias occurs if companies ignore how the propensity to exercise is conditioned on the ratio of market price to exercise price. Finally, some companies introduce biases by selecting particular assumptions about expected exercise and volatility in order to lower their expenses. 
Lang leaves no doubt that employee stock options present a significant claim against companies, which should be reflected in their valuations. And he leaves no doubt that valuation of employee stock options is very complex. Fortunately, he presents an excellent framework for valuing these claims by balancing the obligation of the company to fund outstanding options and future grants with the benefits arising from the incentive effects of options. The Research Foundation is especially pleased to present Employee Stock Options and Equity Valuation.

Mark Kritzman, CFA Research Director The Research Foundation of CFA Institute 


\section{Preface}

One of the most striking developments in compensation has been the growth in importance of employee stock option plans. Stock option plans are pervasive among U.S. companies and of increasing importance internationally. Because options exact a significant cost from the existing shareholders and potentially affect managerial decisions, understanding the effects of options is important to understanding and valuing companies. Furthermore, option accounting has proved very controversial. As the incidence of and controversy associated with options has increased, so has the research literature investigating many of the concerns.

The origins of employee stock options reflect the effort to tie compensation to employee performance. Holmstrom (1979) formalized the notion that companies face a fundamental trade-off in compensating risk-averse employees. On the one hand, incentives can be improved by tying compensation to performance and hence aligning employees' incentives with shareholders'. On the other hand, if employees are risk averse and performance-based compensation places risk on them, the employer will have to provide additional expected compensation for taking on the additional risk.

Option granting began as an executive compensation device because the incentive effects are most clear for individuals who have the ability to significantly affect share price. An increased emphasis on incentive-based compensation along with favorable accounting treatment and other factors have resulted in increased option use over time. Today, options represent a significant component of compensation and a significant cost of doing business for many companies.

As a result, understanding stock option compensation and its implications is important to understanding the company and its value. My goal in this monograph is to provide a general overview on options using evidence from the empirical research literature and financials from Dell Computer Corporation to illustrate various points. Although one could take a number of approaches to evaluating the literature, I structure my discussion around the implications of options for the value of existing shares. And rather than attempting a thorough review of all of the research literature on options, I focus on implications of research for evaluating the likely effect of options on equity valuation. 1

\footnotetext{
1For convenience, I refer to the valuation of existing shares as equity valuation. Options are also equity instruments, but I focus on existing shareholders, reflecting the perspective of an investor assessing the implicit value of outstanding shares.
} 


\section{Employee Stock Option Basics}

To frame the discussion of options and equity valuation, it is useful to consider typical features of employee stock options and a basic approach for incorporating options in valuation. In this chapter, I develop a simple option example to highlight the economic implications of options for existing equityholders. Then, I apply the implications from the example to a standard discounted cash flow model to highlight the effect employee options can have on equity valuation. In later chapters, I use the insights from the option example and equity valuation equation to emphasize the importance of the research findings for equity valuation.

\section{A Typical Employee Option}

Although the length of term varies across companies, a typical option has a 10-year life. Furthermore, the typical option is granted at the money, meaning that the strike price at which the option can be exercised is equal to the stock price at the time of the grant. Therefore, if the stock remains below the price at grant date throughout its life, the option will expire valueless and the employee will have gained nothing. If the stock increases in value, however, the employee has the right to exercise the option and receive the shares at the strike price specified in the option agreement. Typically, an option also carries a vesting period and schedule, such as 25 percent per year at the end of each of the first four years of the option's life, limiting exercise until vesting has occurred. As do option lives, vesting schedules vary across companies.

When employees exercise their options, they receive shares in exchange for paying the strike price. They can then retain the shares or sell them on the market for the current share price, having retained the spread between the market and strike prices (often referred to as the "intrinsic value" of the option). Because employees often exercise for liquidity or to reduce risk, they do not typically choose to hold the stock. Rather, an employee can engage in a "cashless" exercise, often facilitated by the employer or a broker, in which the employee never purchases the stock but simply receives the intrinsic value of the option.

As a result, one can conceptualize the payoffs to the option in terms of a binomial tree, as shown in Figure 1.1. The binomial tree plots potential option values after the initial grant date (Year 0) for cases in which the option is at or in the money. For convenience, I have assumed the stock price can move either up or down each year. At exercise at any node, the employee receives 


\section{Figure 1.1. Binomial Tree for a Typical Employee Stock Option}

\begin{tabular}{|c|c|c|c|c|c|c|c|c|c|c|c|c|c|}
\hline & & & & & & & & & & & & $\begin{array}{c}\text { Share } \\
\text { Price }(\$)\end{array}$ & $\begin{array}{l}\text { Intrinsic } \\
\text { Value (\$) }\end{array}$ \\
\hline & & & & & & & & & & & $x$ & 20 & 10 \\
\hline & & & & & & & & & & $X$ & & 19 & 9 \\
\hline & & & & & & & & & $X$ & & $X$ & 18 & 8 \\
\hline & & & & & & & & $X$ & & $X$ & & 17 & 7 \\
\hline & & & & & & & $X$ & & $X$ & & $X$ & 16 & 6 \\
\hline & & & & & & $x$ & & $x$ & & $X$ & & 15 & 5 \\
\hline & & & & & $\mathrm{V}$ & & $X$ & & $X$ & & $x$ & 14 & 4 \\
\hline & & & & V & & $X$ & & $X$ & & $X$ & & 13 & 3 \\
\hline & & & $\mathrm{V}$ & & $\mathrm{V}$ & & $X$ & & $X$ & & $X$ & 12 & 2 \\
\hline & & $\mathrm{V}$ & & $\mathrm{V}$ & & $x$ & & $X$ & & $X$ & & 11 & 1 \\
\hline & $\mathrm{V}$ & & $\mathrm{V}$ & & $\mathrm{V}$ & & $x$ & & $X$ & & $x$ & 10 & 0 \\
\hline Year & 0 & 1 & 2 & 3 & 4 & 5 & 6 & 7 & 8 & 9 & 10 & & \\
\hline
\end{tabular}

Note: The figure demonstrates possible intrinsic values (i.e., the difference between the stock price and the strike price) for a stock option granted with a strike price of $\$ 10$ when the market price is $\$ 10$. Cases in which share price drops below $\$ 10$ are not included because intrinsic value is zero.

the difference between the current stock price and the strike price. For further convenience, sample stock prices and intrinsic values of the option are listed on the right side of the figure. Therefore, imagine that the stock price is $\$ 10$ at grant date and that it can go up by $\$ 1$ or down by $\$ 1$ each period after grant. Then, in Year 0 (at grant), the option will be worthless if exercised. (Market price is equal to strike price, so intrinsic value is zero.) After one year, the stock price can go up to $\$ 11$ (in which case the option could be exercised at an intrinsic value of $\$ 1$ ) or down to $\$ 9$ (intrinsic value of $\$ 0$ ) and so forth.

To simplify further I have assumed the options vest after four years (although in practice they more typically vest at a rate of 25 percent per year). Assume, further, that no transaction costs are associated with exercising. From that perspective, the option provides incentives to take actions to increase share price prior to exercise so that options are in the money at exercise. In the binomial tree, the nodes marked $\mathrm{V}$ are unvested, so exercise cannot occur. Exercise could occur only at nodes marked with X's.

Several points are worth noting from the figure. First, although issued at the money, the options have value because they have some probability of a positive payoff in the future and no probability of a negative payoff. Although some have argued (and the Financial Accounting Standards Board's [FASB's] intrinsic value approach implicitly assumes) that at-the-money options do not have value at the grant date because they would not have value if exercised at that time, they clearly do have value in expectation because they have upside potential and no downside potential. 
Second, and more importantly, the expected benefit to the employee from holding the option comes at the expense of existing shareholders. This point bears elaboration because some have suggested that options are noncash and, therefore, do not represent a true cost to shareholders under a discounted cash flow approach. For example, if the employee is able to exercise the option at a strike of $\$ 10$ when the share price is $\$ 15$, the employee receives a benefit of $\$ 5$ at the expense of the shareholders, which is clearest with cashless exercise. Suppose the employee exercises the option and immediately sells the share, pocketing the $\$ 5$. As a result, the employee ends up with $\$ 5$ of compensation while the company ends up with $\$ 10$ of additional paidin capital and one more share of stock outstanding. If taxes and transaction costs are set aside, all parties are in exactly the same position that they would be had the company sold the shares on the open market for $\$ 15$ and paid the employee $\$ 5$.

At that point, the company can either allow the additional share to remain outstanding or repurchase it on the open market. The effect of options on equity valuation is easiest to see, however, if one assumes that the company chooses to avoid dilution by repurchasing the stock for $\$ 15$. The underlying economic outcome would be the same had the employee been paid $\$ 5$ in salary (even down to the likely tax effect). The company would have paid out a net amount of $\$ 5$, the employee would have received a net amount of $\$ 5$, and the number of shares outstanding would be unchanged.

Whether or not the company opts to repurchase shares, however, the cost of options accrues to the shareholders. If the company repurchases its shares to satisfy option exercise, it avoids dilution but sacrifices cash. If the company chooses not to repurchase and instead issues more shares, it retains cash but dilutes ownership. Assuming markets are efficient and the cash used for share repurchases would otherwise be invested in zero-net-present-value projects, existing shareholders are indifferent between the two alternatives. But the problem is simplified (without changing the conclusion) if I assume that the company pays the employee the difference between the market and strike prices when the employee exercises an option.

\section{Options in Equity Valuation}

This example provides the framework for thinking about the consequences of options for equity valuation. First, options create a claim against the existing shareholders. Furthermore, one can consider the magnitude of that obligation in terms of the discounted expected cash flows based on the intrinsic value of the option at exercise. 
Second, options create potential benefits to the company's shareholders. Most directly, option compensation is likely to substitute for other forms of compensation that employees would otherwise require. More generally, option compensation changes incentives, which may also change the expected cash flows to the company.

Probably the easiest way to consider options when valuing the equity of a company is to take a cash flow perspective and assume that the company repurchases shares to issue to employees who are exercising options. Then, the cash flow implications of options are most clear without mixing in the effect of dilution.

Similarly, the easiest way to structure the problem is to divide the company into assets, liabilities, and equity:

Assets $=$ Liabilities + Equity .

Following Soffer (2000) and if one assumes no nonoperating assets, the value of the existing equity can be expressed as the value of the net operating assets (net of operating liabilities) less existing interest-bearing (nonoperating) debt.

If the company provides all compensation in the form of salary or bonus and a standard discounted cash flow approach is followed, the value of the existing equity of the company can be expressed as:

Value of common equity

$=\mathrm{PV}$ (Expected operating free cash flows) - Existing debt,

where PV(Expected operating free cash flows) is the present value of the expected operating free cash flows and Existing debt is existing interestbearing debt, including preferred stock.

The next step is to incorporate options. In thinking about the equity valuation effects of options, it is important to be consistent in considering both the likely costs, such as dilution, and the likely benefits, such as improved incentives. If, for example, the cash flow benefits of current and future option grants are to be included in estimating future operating cash flows, the associated cost of those options should also be considered. Initially, I will assume that option grants remain a fixed proportion of compensation; later, I will relax that assumption. 1

\footnotetext{
1Conceptually, an alternate approach would be to assume no future option grants in valuing the existing equity under the assumption that future grants total zero in net present value. But given that the historical data (such as sales growth rates and profitability) reflect the effects of options, fully purging their impact on cash flow forecasts is difficult. At a minimum, some assumption would be required for how much nonoption compensation would substitute for the value of options sacrificed by employees. Furthermore, to the extent that the effect of option compensation is not zero in net present value, ignoring option costs and benefits will misvalue existing equity. As a consequence, explicitly building option forecasts into equity valuation is probably preferable.
} 
Loosely speaking, options could affect Equation 1.2 in at least three ways. First, and most directly, existing options represent an obligation of the company that is not naturally reflected in operating free cash flows and must be explicitly incorporated. From the perspective of the statement of cash flows, for example, options are reflected as a cash outflow from financing (to the extent that shares are repurchased to satisfy option grants) and a cash inflow from financing (for the strike price received when options are exercised). But from an equity valuation perspective, the cost of outstanding options should be taken into account. Although this obligation does not satisfy the accounting definition of a liability, it represents a potentially significant claim against the equity of the company that is conceptually very similar to a liability. In particular, it represents a claim for which the benefits have, at least partially, already been received. Furthermore, if the company were to cease issuing options, the outstanding options would still represent an unavoidable claim against the company. They are contingent obligations because they will need to be satisfied only under certain stock price scenarios. Like a typical liability, outstanding options can be valued based on the present value of the expected option payouts.

Second, the cost of likely future option grants should be considered. As discussed earlier, the issue here is one of consistency. To the extent that the forecasted cash inflows incorporate the anticipated benefits of options, the valuation must also include their costs. Although it may initially seem odd to consider option compensation separately from other compensation, the fact remains that options are different from other forms of compensation because they are not reflected typically on the income statement. As a result, net income is overstated because a major cost of doing business is ignored, but options do conceptually represent an expense and should be taken into account either in expected operating free cash flows or separately. I will take options into account separately under the assumption that the starting point for equity valuation is expected free cash flows based on reported net income, thus ignoring options.

Third, considering the effects of options on expected future operating cash flows is important. That adjustment may be taken into account more naturally because it will directly affect the operating free cash flows of the company. For example, if the company has been relatively consistent in granting options, past experience in generating operating cash flows may be representative in the future. Similarly, the benefits of options will be reflected in net income, so earnings forecasts will incorporate the incentive effects of options. If, on the other hand, the company has recently changed its compensation policy, explicitly taking option incentives into account may be more 
important. The potential adjustment takes two forms. First, options substitute for other compensation, so if the company has been increasing option compensation over time, its growth in reported profitability will be artificially inflated because of the resulting reduction in other forms of compensation that are included as part of compensation expense on the income statement. Second, options have incentive effects that may influence the future cash flow trajectory and risk.

To summarize, therefore, when a company grants options, the equity valuation equation can be supplemented by adding terms to reflect both the expected cost of existing and future options and the expected benefits from the options:

Value of common equity

$=\mathrm{PV}($ Expected pre-option operating free cash flows)

- Existing debt - PV(Expected cost of existing options)

- PV(Expected cost of future options)

+ PV(Expected incremental cash inflows from options). 


\section{Expected Cost of Options}

Conceptually, one way to incorporate existing options when valuing the equity of a company is to include their implications in the forecasted operating cash flow stream. For example, in each future period, the pre-option operating cash flows can be estimated and the cost of satisfying options exercised can be incorporated as part of the cash flow stream.

In practice, however, valuing the option component separately from the other operating cash flows is probably easier because option exercise is difficult to forecast and incorporating option value separately allows one to use existing option-pricing models. In particular, given information on the inputs to an option-pricing model, one can assign a value to the outstanding options and, hence, estimate the magnitude of the obligation.

Before proceeding, however, I will review the accounting and disclosure for stock options, which underpin both the discussion of equity valuation and the review of the research literature.

\section{Accounting for Stock Options}

The primary goal of financial accounting is to provide investors with information they can use to value a company's equity. The challenge for stock option accounting is determining how best to provide the information that investors need to incorporate options properly into equity valuation.

From early on, the Financial Accounting Standards Board (FASB) and its predecessor, the Accounting Principles Board (APB), recognized that options were important to assessing company value. As the use of options grew in importance as a compensation device, so did the need to determine the best way to represent options in the financial statements.

Throughout the extensive discussions of option accounting, two facts have seemed clear. First, an option has expected value (and expected cost to existing shareholders) even if the option is not currently in the money. If the share price increases, the option pays off; if not, the employee receives nothing. But the employee can never lose, so the expected value is positive. Analogously, outstanding options represent an obligation of the company.

Second, options are granted as part of compensation. The employee will find the inclusion of options in the employment contract attractive and may be willing to sacrifice other compensation in exchange for options. In fact, employment contracts often specify an estimated value for options as part of total compensation. Clearly, the value of options represents part of the cost of doing business. 
Based on the notion that options represent value given to the employee as compensation for effort, the FASB has concluded that options should represent part of compensation expense on a company's income statement. The more difficult issue, however, is determining the best method for measuring the value of that compensation.

Measuring and Recording Option Expense. One of the first questions to address has to do with timing: When should the expense be measured and recorded? Conceptually, at least two potential measurement dates exist. One possibility is to wait until the option is exercised, typically years after the grant date, and measure an expense as the value of the option at the point of exercise. This approach is the one taken for tax purposes on nonqualified stock options (NQOs), which will be discussed later. Unfortunately, when using this approach as a basis for stock option accounting in the financial statements, two problems arise. First, in terms of the income statement, it does not match the benefit of options to the cost. The incentive benefits of options are typically received in periods prior to the exercise period. Second, it does not accurately reflect the economics of the transaction. To be analogous with the treatment of other forms of compensation, options should be reflected as a charge against income as they are earned so that two companies granting compensation packages with the same total value are represented on a consistent basis regardless of mix.

The other approach is to measure the value of the option at the date of grant (grant-date accounting) based on an estimate of its value. The APB, and more recently the FASB and the International Accounting Standards Board (IASB), opted for grant-date accounting under the argument that the fair value of the option is established at the granting date. The option value is then expensed over the service period during which the options are earned through vesting, the notion being that options should be recognized as employees gain the rights to them.

The major disadvantage of grant-date accounting is that the value of the option must be estimated at the time of grant, which leads to the most difficult problem in option accounting-how to value an employee stock option. The primary consideration facing most proponents of expensing stock options has been the issue of the appropriate option-valuation approach, and the difficulty of determining the appropriate approach is what, in the past, caused options not to be recognized as an expense. The issue persists even today, with the FASB indicating support for expensing stock options but still discussing the appropriate option-valuation approach.

In that regard, it is instructive to consider the traditional accounting for options in APB No. 25, which was completed in 1973, around the time such articles as Black and Scholes (1973) and Merton (1973) were published. The 
issue facing the APB is clear from the binomial tree in Figure 1.1. Although the general approach to thinking about option valuation seems clear (discounting future expected option values), the practical application is more difficult. For instance, in Figure 1.1, a very limited number of future stock price possibilities exist. In practice, however, with share prices changing constantly and by very small amounts, an almost infinite number of possible future stock price outcomes must be considered, thus complicating the computation. Similarly, the issue of an appropriate discount rate is complex. All these factors make it difficult to comply with the underlying notion of many accounting standards-that resulting amounts must be reasonably and objectively estimable to merit inclusion in the financial statements.

At the time of APB No. 25, the APB argued that options had value and should be recognized as an expense but concluded that the option-valuation approaches were not sufficiently developed to justify applying an optionpricing model. It settled on an approach based on intrinsic value in which options with fixed terms were valued at the grant date based on the difference between market and strike prices (intrinsic value), at least until there was a more generally accepted approach for option valuation. As a result, options issued at the money required no expense recognition, primarily in response to the lack of an acceptable option-valuation approach.

Arguments against Expensing Options. With the general acceptance of the Black-Scholes model and other option-pricing models for publicly traded options and the increasing use of options in practice, the issue of option measurement became more pressing. Many commentators noted the inconsistency in accounting between stock options and other forms of compensation. In fact, even with stock options, grants to nonemployees (such as for goods or services) were required to be recognized as an expense based on option-pricing models, with only option grants to employees accorded special treatment. Companies issuing substantial nonoption compensation argued that they were unfairly disadvantaged by the special treatment accorded options. As a result, the FASB agreed to reconsider the option issue.

Although many arguments were raised against the expensing of options, the most compelling were (1) that there were economic consequences to option expensing and (2) that the value of options could not be accurately estimated. 1

\footnotetext{
1For convenience, I refer to the accounting issue as relating to whether options should be expensed. But the issue is not primarily about expensing options per se (because current accounting requires that the intrinsic value of options be expensed) but, rather, about how the expense should be measured and whether it should reflect the fair value of option compensation (computed based on an option-pricing model such as Black-Scholes).
} 
Regarding the economic consequences, some critics asserted that even if the current accounting were incorrect, the cost of changing it (in terms of harming the competitiveness and capital-raising ability of high-technology companies) would be too high. But the FASB has indicated on a variety of issues (such as expensing research and development and accounting for postretirement benefits) that economic consequences are not a major consideration in its deliberations and that accounting is intended to be neutral (that is, accounting should report on economic reality without affecting it). The FASB views the current accounting for options as nonneutral because companies appear to change the structure of option contracts (such as issuing options at the money) to avoid expense recognition.

Option-Valuation Concerns. The concerns over option valuation are more substantive. As many commentators have noted, existing option-pricing models are based on assumptions that are generally not designed for employee stock options. Furthermore, although option-pricing models work well for publicly traded options, they may not be as effective for employee stock options.

Under pressure from a variety of sources, the FASB opted in SFAS No. 123, Accounting for Stock-Based Compensation, to encourage companies to expense the fair value of options but offered the alternative of disclosure. ${ }^{2}$ More importantly from an equity valuation perspective, the FASB established a set of required disclosures to inform valuation so that even if the company chose not to expense options, sufficient detail was available for investors to estimate the value of existing options and likely future options. The resulting disclosures include the fair value of the options earned by employees during the period as well as information about the characteristics of options currently outstanding.

To understand the disclosures, it is useful to explicitly consider the inputs into a model such as the Black-Scholes option-pricing model because the disclosures are designed to help investors who are using such a model to arrive at their own estimates.

The basic Black-Scholes model for a non-dividend-paying stock expresses option value as follows:

$$
C=S N(D 1)-K e^{-r t} N(D 2),
$$

2The full text of SFAS No. 123 is available online at www.fasb.org/pdf/fas123.pdf. 
where

$C=$ the value of the option

$S \quad=$ the current market price of the stock

$K=$ the strike price to be paid when the option is exercised

$t \quad=$ the time remaining before the option expires

$N(\bullet)=$ the cumulative standard normal density function

$r \quad=$ the risk-free interest rate

$\sigma \quad=$ the standard deviation of the return on the stock

$$
\begin{aligned}
& D 1 \equiv \frac{\log (S / K)+\left(r+\sigma^{2} / 2\right) t}{\sigma \sqrt{t}} \\
& D 2 \equiv \frac{\log (S / K)+\left(r-\sigma^{2} / 2\right) t}{\sigma \sqrt{t}} .
\end{aligned}
$$

The first term of the equation can be thought of as the present value of receiving the stock at exercise conditional on the option being in the money. The second term captures the present value of having to pay the exercise price conditional on the option being in the money. The difference is the value of the option.

If the company is expected to pay dividends, the Black-Scholes model can be supplemented with an adjustment for dividends. In particular, because options are not typically dividend protected and because dividends substitute for capital gains, the value of an option on a stock that pays dividends is reduced relative to the value of an option on the same stock if it paid no dividends. The adjustment basically represents the present value of the dividends that would be sacrificed by holding the option rather than the underlying stock. If one assumes that the stock pays dividends continuously at a constant dividend yield and that options are held to maturity, the optionpricing model can be adjusted by substituting $S_{\text {Dividend }}$ for $S$ in the BlackScholes model, where

$$
S_{\text {Dividend }}=S e^{-\delta t} \text {, }
$$

and where $\delta$ is the annual dividend yield as a percentage of the current market price of the stock. 3

3The adjustment is an approximation because, for tractability, it assumes that option exercise is unaffected by dividends and that dividends are paid continuously. In practice, the presence of dividends may induce early exercise to capture the dividend and dividends are typically paid periodically rather than continuously. Adjustments to reflect the effects of dividends on option value more accurately are discussed in Hull (2002). 
The Black-Scholes model is well suited for estimating the value of the option obligation because it provides an estimate of the present value of the future payoffs to the option. As a consequence, it does not require that the potential values of the options be forecasted then discounted back but instead permits the value to be inferred from inputs-such as the current market price, option strike price, risk-free interest rate, expected share price volatility, dividend payout, and expected time to exercise-to calculate the value of an option.

\section{Dell Example}

To understand how such an approach might be implemented in practice, I will apply it to Dell Computer Corporation. The appendix presents financial statements and selected disclosure from Dell's fiscal 2002 annual report, including the option footnote.

Footnote Disclosure. Note that the option footnote presents five basic sets of information. First, it provides information on the terms of the options. For example, it notes that there are two option plans-one for executives and one for nonexecutive employees (the broad-based plan). In terms of the tax treatment of the options, the broad-based plan is limited to nonqualified options; the executive plan includes both nonqualified options and incentive stock options. Dell's options typically have a 10 -year maturity and vest over 5 years. That information will be useful in estimating the value of the options.

Second, it provides information on the option granting, exercise, and cancellation behavior in previous years. For example, it shows that 344 million options were outstanding at the beginning of 2002, 126 million more were granted, 63 million were exercised, and 57 million were canceled, leaving 350 million outstanding at year-end.4 Given 2,602 million total shares outstanding at year-end, optioned shares represent 13.5 percent of shares outstanding. In addition, it shows the average exercise prices of each group of options. For example, it shows that the options granted during 2002 were at an average strike of $\$ 23.24$ and those that were exercised were at a strike of $\$ 3.11$, indicating that the share price increased about 647 percent on average since those options were granted. In addition, options canceled had an exercise price of $\$ 32.86$, indicating that most were out of the money when the employee left the company. Such information is useful in forecasting option activity going forward.

\footnotetext{
4For convenience, I quantify options based on the number of underlying shares of stock to which they pertain. For example, I refer to 344 million options rather than the technically more correct options on 344 million shares of stock. I also refer to years based on the end of Dell's fiscal year, so the fiscal year ending 2 February 2002 is referred to as 2002 .
} 
Third, the disclosure provides a summary of the terms of the options that were still outstanding at the time of the statement. In particular, the outstanding options are categorized by exercise price range, and Dell also discloses weightedaverage exercise price and remaining contractual life. Options are divided into those that are exercisable and those that are not (typically because they have not vested). That information provides useful inputs into the option-valuation model.

Fourth, the footnote presents information on fair value estimates and the assumptions underlying those estimates. In particular, the footnote indicates that Dell estimates that the average fair value of an option granted in fiscal 2002 was $\$ 13.04$, down from $\$ 20.98$ and $\$ 22.64$ in 2001 and 2000 , respectively, primarily because of lower share prices. Furthermore, the footnote provides estimates of the reduction in income had options been expensed, on both a pretax and after-tax basis, as well as on a per-share basis. In 2002, expensing options would have reduced pretax income by $\$ 964$ million, $\$ 694$ million after tax. Given a reported pretax income of $\$ 1,731$ million, expensing options would have represented a reduction of 56 percent. In terms of an equity valuation framework, this information is useful in thinking about current option intensity (and profitability) as a means of assessing the likely cost of options in the future. In that sense, options are like other forms of compensation on the income statement, and the footnotes provide information on current profitability after taking options into account as a means for estimating future profitability.

Finally, regarding the assumptions underlying the fair value estimates, the footnote shows that expected life on new option grants is 5 years (relative to a contractual life of 10 years), the risk-free rate is 4.63 percent, the share price volatility is 61.18 percent, and no dividends are anticipated.

Value of Outstanding Options. With the information provided by Dell, estimates of the inputs listed below can be developed, which can then be used to estimate the value of outstanding options using Equation 2.1:

$S=$ the current market price of the stock

$K=$ the strike price to be paid when the option is exercised

$t=$ the time remaining before the option expires

$r=$ the risk-free rate of return

$\sigma=$ the standard deviation of the return on the stock

$\delta=$ the annual dividend yield

The footnote discloses, as mentioned previously, the following option assumptions as of year-end 2002:

- Risk-free rate ( $r$ in the Black-Scholes model) is 4.63 percent.

- Standard deviation of returns ( $\sigma$ in the model) is 61.18 percent.

- Expected dividend yield ( $\delta$ in the model) is zero. 
The footnote also discloses information on the terms of various subsets of options. For example, the set of 30 million options outstanding has an average remaining contractual life of 3.49 years and a strike price ( $K$ in the BlackScholes model) of $\$ 0.96$. The strike price can be compared with Dell's share price at fiscal year-end 2002 ( $S$ in the Black-Scholes model) of $\$ 26.80$.

The only missing input for calculating the option value as of year-end 2002 is the expected remaining life; yet even for expected remaining life, some information is available. First, Dell's disclosure shows that the expected term at time of grant for the typical option is five years. Second, it shows that the options in this group are, on average, already more than five years from grant and have a remaining contractual life of only 3.49 years. As a result, the remaining life for this particular group of options cannot exceed 3.49 years. Although I discuss approaches for developing more sophisticated estimates of option exercise later in this monograph, at this point I will assume that exercise takes place at half of the remaining life (in 1.745 years for this group of options).

Using this available information and applying the Black-Scholes pricing model, the value of each option is about $\$ 25.91$. The option value is very close to the intrinsic value of the options (market price of $\$ 26.80$ - strike price of $\$ 0.96=\$ 25.84$ ) because the options are deep in the money and close to the end of their lives and, hence, are very likely to be exercised. Multiplied by 30 million, that group of options is worth about $\$ 777$ million.

Analogous calculations can be made for the other option subsets as well, and by continuing, for convenience, to assume that options are exercised halfway through their remaining lives, the total value of outstanding options is found to be $\$ 5,257$ million. Because, as discussed in more detail later, option exercise typically creates tax deductions, the implications for cash flows are not as extreme as the magnitude of that liability would imply. But assuming a tax rate of 28 percent, the after-tax liability is about $\$ 3,785$ million.

At year-end 2002, Dell had total liabilities of $\$ 8,841$ million; therefore, options would increase the liabilities by 43 percent. Given a market capitalization of $\$ 69,734$ million as of year-end 2002 , the after-tax value of outstanding options is 5.4 percent of the market value of Dell's outstanding equity. If treated as a liability, the option obligation would represent one of the largest claims against the company.

Future Option Grants. If one assumes that the operating cash flow estimates do not explicitly incorporate the effects of options, future option grants need to be taken into account. Based on the footnote disclosure, stock options could have a substantial impact on Dell's reported profitability. In particular, the pro forma disclosure indicates that diluted earnings per share in 2002 would have been reduced by $\$ 0.27$ per share-from $\$ 0.46$ to $\$ 0.19$. In other words, 
based on the valuation approach used by Dell, options constituted a substantial cost of doing business. Coupled with the valuation approach just demonstrated, one could use this information (and information on the prior years' options) to assess the quantity of options necessary to support past accounting profitability and get a sense of the intensity of options likely needed for the future.

Dell's statements show that pro forma option expense totaled \$964 million in 2002, but that figure includes a mixture of effects. First, it includes a portion of the options granted in each of the last five years (because Dell has a fiveyear vesting plan and option expense is spread out over the vesting period). As a result, the $\$ 964$ million reflects options granted as far back as 1997 , which also explains part of the reason that pro forma option expense increased substantially over recent years. In SFAS No. 123, the FASB established a transition in which the footnote expense was based only on grants going forward, so the first year included only that year's option grants. As time passed, additional layers of option grants were added until the calculation reached steady state at the end of the vesting period for options granted in the first year of the standard (five years in Dell's case). As a result, the trend in historical data on pro forma option expense is not necessarily representative going forward. Second, under SFAS No. 123, option values are adjusted for estimated forfeitures. The company estimates the value per option and the likely forfeitures during the vesting period. The remaining amount is amortized over the vesting period, with an adjustment each period for the amounts by which the forfeiture rate differs from expectations. As a result, the $\$ 964$ million is affected by the option grants over the previous five years and the experience with forfeitures.

In 2002 , the total value of Dell's options could be computed as $\$ 1,643$ million (126 million options granted $\times$ an option value per share of $\$ 13.04$ ). In 2001 , the total was $\$ 3,231$ million ( $\$ 20.98 \times 154$ million), and in 2001 , it was $\$ 1,132$ million $(\$ 22.64 \times 50$ million). The volatility of option grants makes them difficult to forecast in this context, and knowledge of the company's plans with respect to options is important for forecasting options. But as a starting point, the value of options granted from 2000 to 2002 averaged $\$ 2,002$ million. During those same three years, cancellations on Dell's options averaged 33 percent. Although that average probably overstates the effect of cancellations because it includes outof-the-money options that were canceled but would otherwise have expired out of the money, it provides at least a benchmark for thinking about options going forward. Assuming that 33 percent of the options are ultimately canceled and applying Dell's stated effective tax rate of 28 percent, one can see that the pretax option amount is $\$ 1,341$ million and the after-tax amount is $\$ 966$ million. 
The notion that Dell incurred about $\$ 966$ million of after-tax option costs in 2002 provides at least a starting point for thinking about future option costs. If option intensity were to remain relatively constant, the cost of option-based compensation might be expected to grow at approximately the growth rate of sales. Starting with a baseline expense of $\$ 966$ million and assuming a growth rate of, say, 3 percent in perpetuity and an 8 percent discount rate, the estimated obligation created by future option grants would total about $\$ 19,315$ million. Coupled with the estimated obligations for existing options discussed earlier, the total obligation for current and future options would total $\$ 23,100$ million. Comparing that amount with Dell's year-end market capitalization of $\$ 69,734$ million, the cost of options is clearly substantial.

Of course, the preceding is based on fairly ad hoc assumptions and, in practice, would need to be adjusted for expectations about future events, especially with regard to future option grants. For example, many companies, including Dell, have announced intentions to reduce option intensity going forward. But even if that is the case, companies such as Dell will likely have to substitute other types of compensation for the portion of compensation currently in options. As a result, the effects of an overestimate of option compensation will be mitigated potentially by an underestimation of other compensation. In the extreme, if other compensation replaces option compensation dollar for dollar, an inaccurate estimate of options going forward does not necessarily create an inaccurate estimate of value. As discussed later, however, the trade-off need not be dollar for dollar because of such factors as risk aversion.

\section{Tax Issues}

From an equity valuation perspective, incorporating the tax effects of employee options can be quite important because the tax deduction can significantly reduce the cost of options. When examining the tax issues, one must consider the two major classes of stock options-incentive stock options (ISOs) and nonqualified stock options (NQOs) —although ISOs have declined in importance.

Incentive stock options are restricted because they must meet certain IRS criteria, including requirements that the underlying stock not be sold for two years after the option is granted and for one year after the option is exercised. ISOs provide no tax deduction to the issuing company and no taxable income to the employee at exercise. But when the underlying stock is sold, the employee must pay tax on the difference between the selling price and the purchase price (the option strike price), usually at the capital gains rate. 
Nonqualified stock options do not carry the same restrictions and require the employee to pay taxes at the ordinary income tax rate on the difference between the market price and strike price when the options are exercised. In addition, the company receives a tax deduction in the same amount at that time. Prior to the Tax Reform Act of 1996, many options were ISOs because the ordinary income tax rate for individuals was quite high relative to the capital gains rate and the corporate tax rate. But the Tax Reform Act of 1996 reduced the attractiveness of ISOs from a tax perspective.

Although some companies still have some ISOs, the majority of outstanding options are now NQOs. Furthermore, those companies that continue to hold ISOs do not typically separate them from NQOs. For example, Dell notes that its broad-based option plan contains only NQOs. The executive plan, in contrast, contains a combination of ISOs and NQOs, but the split is not stated. In addition, Dell's proxy statement indicates that the options granted to executives represent only about 10 percent of options granted to all employees, so I will assume that all options are NQOs.

The tax implications of stock options are not conceptually different from those of other forms of compensation because such other forms also typically provide a tax deduction when the value is received by the employee. But two important factors set NQOs apart. First, the tax treatment of NQOs is based on exercise-date accounting, whereas the financial accounting treatment is based on grant-date accounting. As a result, at the time options are granted to employees, their value is represented as an expense or (more commonly) in the footnotes at the modified Black-Scholes value of the option based on expected payoff. For tax purposes, however, the deduction is based on the intrinsic value at the time of exercise. Therefore, even if options are expensed for financial accounting purposes, the tax and accounting treatments can differ drastically in terms of timing and amount. Second, the amounts of option deductions can be extremely large for a company if it has experienced a substantial stock price run-up. Not only will the deduction per share exercised be large, but option exercise will also be more prevalent.

For a comfortably profitable company with a relatively modest stock option plan, treating the tax effects of stock options is fairly straightforward. Because the stock option is valued based on the expected intrinsic value at exercise, which also represents the expected tax deduction, the after-tax option value can be approximated by subtracting the likely tax benefit resulting from the option exercise (expected corporate tax rate times the expected intrinsic value) from the pretax value. This is the approach used earlier to determine the basic equity valuation for Dell. 
The situation becomes more complex if the company is likely to experience a tax loss during the period when the option is exercised. Although such a tax loss should be a concern for any tax deduction, it is particularly pronounced for stock options because of the possibility that an otherwise profitable company can realize so much in stock option deductions that it reports a tax loss.

The effect of options on taxes can be substantial even for large companies. Sullivan (2002), for example, estimated that the tax deductions for options exceeded net income for 8 of the 40 largest U.S. companies in 2000-Microsoft Corporation, America Online, Cisco Systems, Amgen, Dell, Sun Microsystems, Qualcomm, and Lucent Technologies. Graham, Lang, and Shackelford (forthcoming 2004) estimated that option deductions totaled 10 percent of pretax income for S\&P 100 Index companies during 2000. Even more striking, aggregate option deductions exceeded aggregate pretax income for the NASDAQ 100 Index companies in 2000 (although some did pay taxes because the deductions did not exceed pretax income for some individual companies). Therefore, one cannot assume that option-intensive companies that are profitable on an accounting basis also have positive taxable income.

Option Tax Effects on Cash Flows. Current accounting and disclosure create a challenge for understanding the past effect of options on taxes because if the underlying options are not treated as an expense for financial accounting purposes, then they also do not reduce income tax expense. The reason for the parallel treatment is fairly clear. If options reduced income tax expense but not pretax income, the net effect of issuing options would be to increase income (reduce tax expense but not pretax income). In addition, effective tax rates would appear to be unreasonably low because tax expense would be reduced by the effects of options but pretax income would not be reduced.

Instead, stock option tax benefits do not directly affect tax expense on the income statement, either when the options are granted or when they are exercised. Furthermore, because they never affect tax expense, deferred tax is not typically created. As a result, the tax/book difference for options never reverses, so a company could have significant tax expense on the income statement without ever paying taxes. Further still, the changes in the deferred tax accounts are not informative about the tax effects of options because deferred-tax accounting is generally not required.

A similar issue exists with respect to pretax income. Because options are not deducted as an expense when issued, they never directly affect pretax income. Finally, because the tax benefits from options flow through the operating section of the statement of cash flows, a company can report high profits and even higher operating cash flows. 
In some cases, it is possible to get a sense of the likely size of the tax effect of options from the statement of cash flows or the statement of shareholders' equity. In particular, when options are exercised, the typical accounting for the tax effect is as follows:

Taxes payable

Additional paid-in capital

In theory, one should be able to infer the amount of the tax benefit from the statement of shareholders' equity. But many companies combine different effects of options on the same line. For example, by reading Dell's financial statement, investors would know that Dell had "Stock issuances under employee plans, including tax benefits" of $\$ 853$ million in 2002, but investors would not know how much the option exercise itself was (which would also have affected additional paid-in capital) nor how much the tax benefit was.

Similarly, the statement of cash flows disclosure is inconsistent, and the effects of options are often not separated, especially for smaller magnitudes. For example, Hanlon and Shevlin (2002) found that only 63 of the NASDAQ 100 companies separate out the tax benefits of stock options, even though they are likely to be especially option intensive. Furthermore, interpreting information on option tax benefits is complex in cases of net operating loss carryforwards and tax valuation allowances. As a result, Hanlon and Shevlin advocated using the tax footnote information to estimate the tax effect of options.

It is clear from Dell's stock option footnote that the effect of options on taxes can be significant. For example, one can estimate the size of the option tax deduction by taking into account the number of shares exercised in each year and then estimating the degree to which the underlying options are in the money. The footnote provides information on the weighted-average strike price but not on the market price. An estimate of the market price at exercise, however, can be based on the weighted-average strike price on options granted during the year if the company typically issues at the money, or it can be based on the actual stock price path during the year.

Using the information from the footnote, Dell's option deductions for 2002 can be estimated as $\$ 1,268$ million [63 million shares $\times(\$ 23.24-\$ 3.11)$ ], which compares with pretax income on the income statement of $\$ 1,731$ million. Dell, therefore, appeared substantially more profitable for financial accounting purposes than it did on its tax return. Similar calculations estimate that Dell had $\$ 3,279$ million of deductions relative to $\$ 3,194$ million of pretax income in 2001 and $\$ 3,109$ million of deductions relative to $\$ 2,451$ million of pretax income in 2000. Therefore, despite substantial pretax accounting income in 2000 and 2001, Dell received tax refunds. 
Consistent with that result, Dell's supplementary statement of cash flow disclosure indicates that not only did Dell not pay income taxes in 2000 and 2001 ; it actually received cash back (refunds of prior taxes paid) of $\$ 32$ million in 2001 and $\$ 363$ million in 2000. Assuming a tax rate of 28 percent, Dell had a tax benefit from options of about $\$ 355$ million, $\$ 918$ million, and $\$ 871$ million for 2002, 2001, and 2000, respectively. These amounts can be compared with the amounts of tax benefits from option exercise reported on the statement of cash flows of $\$ 487$ million, $\$ 929$ million, and $\$ 1,040$ million. The difference reflects, at least in part, the timing lag between the month when options are exercised and the month when taxes are paid, as well as assumptions on tax rates and stock prices.

The statement of cash flow effect of options is particularly important to note because it is included in the operating section. For example, in 2000, Dell's operating cash flow was $\$ 3,926$ million, substantially exceeding its net income of $\$ 1,666$ million. The difference is largely the result of the $\$ 1,040$ million in tax benefits from options, which are not comparable to normal cash from operations.

Note also that the deduction for tax purposes differs markedly from the pro forma expense in the footnotes. Even if options had been expensed on the income statement in 2001, for example, the tax deduction of $\$ 3,279$ million estimated earlier would have been far greater than the financial statement expense of $\$ 620$ million noted in the footnotes. The reason, of course, is that the income statement expense represents the ex ante value of options earned by employees in the current year and the tax return represents the ex post value of the options exercised in the current year. The $\$ 620$ million represents an expectation of what the grants earned during the year will be worth ultimately (discounted back to the present). The $\$ 3,279$ million is the amount that options granted in the past were ultimately worth when exercised. Although fewer options were exercised in 2001 (95 million) than were granted in 2001 (154 million), the fact that the options exercised in 2001 were worth substantially more than those included in the expense in 2001 reflects the average share price appreciation (from $\$ 3.26$ to $\$ 37.78$ ) from the time when the options were granted to when they were exercised.

To get a sense of the difference between ex ante and ex post value, one can use Dell's information on its 2001 option grants, which had an average strike price of $\$ 37.78$, with an average fair value of $\$ 20.98$, or 56 percent of the strike. Applying the same proportion to the options exercised in 2001 (and assuming other inputs to the option-valuation formula remained approximately constant), the per-share fair value of the options exercised in 2001 was $\$ 1.81$ per option $(\$ 3.26 \times 0.56)$ or $\$ 172$ million total $(\$ 1.81 \times 95$ million $)$ 
when they were granted. In other words, the pro forma expense when the options were issued would have been about $\$ 172$ million, with the options ultimately providing deductions of $\$ 3,279$ million. By the same token, the $\$ 172$ million of options could easily have expired worthless had the stock price not risen.

This illustration also clarifies the difficulty of matching financial accounting for options to tax accounting for options. The $\$ 172$ million represents the present value of an estimate of the value of the options when granted; the $\$ 3,279$ million represents the realized value. Had Dell been required to expense options from a financial statement perspective, it would have appeared to have been quite profitable, but from a tax perspective, its profitability was substantially lower. This tax/book difference never reverses because financial accounting records an estimate of the value of the option at grant (grant-date accounting) and does not adjust it to the ultimate value at exercise on which the option deduction is based (exercise-date accounting). As a consequence, a company can look consistently profitable for financial accounting purposes while paying little or no tax.

Note also that the amount of the option deduction can vary dramatically over time. For example, the estimated option deduction increased from $\$ 3,109$ million in 2000 to $\$ 3,279$ million in 2001 and then dropped to $\$ 1,268$ million in 2002. Similarly, the cash flow effects are volatile-from $\$ 871$ million in 2000 , based on my estimates, to $\$ 918$ million in 2001 and $\$ 355$ million in 2002 .

Furthermore, although Dell faced a large number of in-the-money options in 2000 (363 million options at the beginning of the year, with an average strike of $\$ 5.40$ and an average stock price of $\$ 42.86$ during the year), by the end of 2002 the options outstanding were, on average, close to the money (350 million options with an average strike of $\$ 26.36$ and share prices averaging $\$ 23.24$ during 2002). As a result, the massive cash benefits from stock options are unlikely to recur unless Dell's stock price increases substantially.

From an equity valuation perspective, the important point is forecasting the tax implications of options for future cash flows. As is clear from the Dell example, option deduction cash flows are unlikely to remain constant over time because they are very sensitive to share price movements. But the optionpricing model offers an effective method for computing the present value of the option deductions. Assuming a constant tax rate (28 percent in Dell's case), one can simply apply that rate to the fair value of the options to compute the present value of the expected tax shield. That factor was implicit earlier when I assumed that the after-tax option obligation was 72 percent of the gross amount. 
Unfortunately, the assumption that option deductions can be fully utilized as realized may not be valid for many companies. As the preceding example illustrates, even a company as profitable as Dell can face situations in which option deductions can exceed pretax income. Under some circumstances, many companies will face no significant tax burden because of tax losses. In fact, the presence of large stock option deductions creates the possibility that companies that appear profitable from an accounting perspective may actually report tax losses once deductions are included.

Because of the carryforward and carryback features of the tax code, four potential scenarios can be projected. Scenarios 1 and 2 present extreme situations in which few companies are likely to fit. Scenarios 3 and 4 are more probable.

1. The company is always profitable from a tax perspective (in all states of the world and over all time periods from 3 years prior to the current year to 20 years subsequent to the current year) and able to use the tax deductions in the year of exercise. In that case (and assuming a constant tax rate), the deductions can be valued at the tax rate multiplied by the value of the options, and the after-tax option obligation can be measured at 1 minus the tax rate times the pretax option obligation. This scenario, however, describes only the most stable and profitable companies.

2. The company is always unprofitable from a tax perspective; hence, the tax deductions will expire unused. In this scenario, the deductions are worthless and the after-tax value of the option obligation is the same as the pretax value. This scenario is also unlikely to describe many companies because companies that are going concerns have a significant probability of at least some profitability.

3. The company is expected to have tax profits in the year the options are exercised (at least in some situations) but is expected to be unprofitable in some other years.

4. The company is expected to have tax losses in the year the options are exercised (at least in some situations) but is expected to be profitable in some other years.

In the last two scenarios, the present value of the tax benefit will depend on the proportion of situations in which the company is expected to be tax profitable in the year the options are exercised as well as its profitability in years around that year. Even an unusually profitable company such as Dell can have years when option deductions wipe out all taxable income so that some deductions cannot be used in the current year. But if the company was profitable in past years, it can carry the loss from the excess option deductions back to get refunds for prior taxes paid. As a result, it still generates a full tax benefit. 
Similarly, if the company is expected to be profitable in the year of exercise but likely to be unprofitable in the future, the deductions will initially generate tax benefits. But those tax benefits will disappear when the company becomes unprofitable because the taxes saved would have been refunded anyway.

Findings of Graham, Lang, and Shackelford. Graham, Lang, and Shackelford developed an approach for forecasting the relevant marginal tax rate in the face of stock options. Their question is slightly different from mine because they attempted to assess the effect of options on the tax benefits of debt. They considered realized option deductions in 2000 and attempted to assess the marginal tax rate faced by a company considering the simulations of future pretax income and option exercise based on past experience. They focused on the S\&P 100 and NASDAQ 100 companies and used information from the option footnote to forecast likely carryforward and carryback implications of options. They used a simulation in which the past distribution of share prices and pretax, pre-option earnings was used to forecast potential tax positions and probabilities in each year going forward. Given that information, probability-weighted expectations can be formed that explicitly take into account (1) the likelihood that the option deductions will be exploited and (2) the amounts of likely deductions.

They made several important observations. First, even for the S\&P 100 sample, option deductions totaled $\$ 63$ billion on pre-option, pretax income of $\$ 349$ billion. As a consequence, the companies faced a substantially lower tax burden than implied by income tax expense on the income statement. But taking into account the option deductions, the average S\&P 100 company still faced a marginal tax rate of 35 percent, indicating that although the deductions were large, the average S\&P 100 company could fully use its option deductions. Even if deductions were expected to exceed pretax income under certain circumstances (as with Dell), S\&P 100 companies typically can use tax loss carrybacks to obtain refunds of previous taxes paid or carryforwards to offset future taxes.

The NASDAQ 100 companies, in contrast, had option deductions of \$35 billion on pre-option, pretax income of $\$ 13$ billion. In other words, although the NASDAQ 100 appeared profitable in aggregate when one ignores options, that perspective changes when options are factored in. But because some companies were profitable even after taking options into account and others had large losses, some NASDAQ 100 companies still paid taxes.

More to the point, when options are ignored, the average NASDAQ 100 company had an estimated marginal tax rate of 31 percent, suggesting that most companies were facing relatively high tax rates. But when options are factored in, the marginal tax rate drops to 5 percent, with almost 60 percent of the NASDAQ 100 companies facing estimated marginal tax rates of less than 10 percent. 
One way to interpret that result is that most companies were able to use at least part of their 2000 option deductions (because they were tax profitable before taking into account the option deduction), but many were not expected to be able to use all of their option deductions (because they were expected to be unprofitable for some time in the future after taking into account their option deductions). In some cases, the reduction in marginal rates reflects the fact that the company would not be able to take advantage of the deductions for many periods in the future (because it was not expected to be profitable for some time) and would, therefore, sacrifice the time value of money. In extreme cases, however, companies had not been profitable in the past and were not expected to be profitable in the foreseeable future; therefore, although options generated large tax deductions, those deductions were expected to expire unused.

An implication of this result is that, although options may provide substantial tax deductions to offset a portion of their cost, one cannot assume that the full amount of the tax deduction can be exploited. In cases of stable, profitable companies, the after-tax cost of options can be approximated by multiplying the pretax cost by 1 minus the company's tax rate. But in cases of less stable, less profitable companies, the option deductions may expire unused or may not be used for several periods in the future, sacrificing the time value of money.

Graham, Lang, and Shackelford also examined whether companies behave as though they recognize the effect of the likely option deduction in making financing decisions. In particular, they examined why some companies issue relatively little debt despite high accounting profits (given that it appears that debt would reduce expected tax burdens) and hypothesize that many such companies do not anticipate paying much in taxes. Therefore, if one views the decision on debt policy after all of the company's other decisions have been made, a company that looks profitable from an accounting perspective may actually view itself as unlikely to pay taxes and may, therefore, view debt as unattractive. Consistent with that result, Graham, Lang, and Shackelford documented relatively little relationship between debt levels and marginal tax rates when the effects of options were ignored. But when options are factored in, a significant relationship exists between debt and tax rates, thereby reinforcing the importance of considering options when examining companies' financial decision making.

Although options represent a significant cost of doing business, the cost is mitigated by the tax benefits options provide. Furthermore, a thorough understanding of option taxes is critical when interpreting current cash flows and predicting future cash flows. 


\section{Patterns of Option Exercise}

Every option-valuation approach makes assumptions about the behavior employees will follow when exercising their options. Consider the binomial tree in Figure 1.1. In a large number of cases, the option is in the money and exercisable, and it is up to the employee to decide when to exercise. But to make the valuing of options manageable, some assumptions must be made about the circumstances under which exercise occurs.

\section{Assumptions about Exercise}

One of the major insights underpinning the traditional Black-Scholes model for traded options is that one can infer optimal exercise. In particular, for options that are tradable on non-dividend-paying stocks, early exercise is generally not optimal. 1 As a result, for most traded options, exercise can be assumed to occur whenever the option is in the money at the end of its life, and no earlier. Therefore, option valuations can be developed based on forecasting stock price paths through to option expiration, attaching probabilities, and discounting back to the present. In terms of Figure 1.1, that assumption would imply exercise in all cases in the 10th year (conditional on the option being in the money).

In part, the optimality of exercise only at maturity reflects the fact that, besides being exercised, publicly traded options can be sold or hedged, so an individual's risk profile and liquidity needs do not enter into the calculation. Conversely, employee stock options generally cannot be sold, and employees are limited in their ability to lay off risk by taking, for example, a short position to offset the long position in the option. Although an employee might like to sell an option, selling it would defeat the incentive intentions in granting the option because the new buyer would typically not have the same ability to affect company value.

As a consequence, factors such as an employee's level of risk tolerance and liquidity needs affect exercise decisions and thus increase the complexity of forecasting option exercise. For example, an employee requiring cash for a major purchase or wishing to reduce exposure to the company's stock may have little choice but to exercise options even if the remaining contractual life is substantial. In order to accurately estimate option value, therefore, forecasting the likely employee option exercise behavior is necessary.

1For high-dividend stocks, early exercise is sometimes optimal immediately preceding a dividend to capture the dividend, because options are typically not dividend protected. 


\section{Timing of Exercise}

Unfortunately, employees are unlikely to exercise their options at the same time or based on the same factors. Exercise is likely to be triggered by employee-specific events. For example, employees may exercise early because of risk aversion or liquidity concerns, and risk aversion and liquidity needs will vary from employee to employee. Furthermore, employee stock option exercise may be involuntary (or only partially voluntary), such as when the employee separates from the company, because options are typically canceled if not exercised within a specified time from separation.

As a result, rather than identifying a subset of nodes at which exercise is definitely optimal, envisioning nodes with various probabilities of exercise is probably more accurate. One can, for example, imagine the probability of exercise changing based on factors such as the remaining life of the option, the market price/strike price ratio, or recent share price volatility.

Exercise patterns not only affect option valuation; they can also have an impact on a company's cash flow needs. For example, a company that chooses to repurchase shares to satisfy option exercise (hence avoiding dilution) will have substantially greater cash flow needs in periods when many deep-in-themoney options are exercised. Similarly, companies that issue new shares for option exercises will have significant cash inflows as the strike price is received from employees. In Dell's case, for example, the 63 million options exercised in 2002 generated about $\$ 196$ million in cash from the strike price $(\$ 3.11 \times 63$ million $)$. As discussed earlier, option exercise would also have generated about $\$ 355$ million in tax savings in 2002 . But had Dell opted to repurchase those shares to avoid dilution, it would have had to pay about $\$ 1,464$ million ( $\$ 23.24 \times 63$ million), assuming that the options were repurchased at the same price as the new options granted during the year. As a result, repurchasing shares for option exercises would have cost Dell $\$ 913$ million, net of strike price and option tax benefits received. An analogous calculation for 2001 indicates a cost of $\$ 2,361$ million to repurchase shares to satisfy option exercise, net of strike price and option tax benefits received. Even for a profitable company such as Dell, repurchasing shares to satisfy option exercise entails a substantial cash outflow.

One thing that seems clear is that early exercise is an important phenomenon and one that must be considered. Casual observation and academic research point to the pervasiveness of early exercise. Exercise typically occurs as early as halfway through the option's life, as in Dell's case when exercise is assumed to occur, on average, 5 years into the option's 10-year life. Furthermore, the cost to the company of a 10-year option is substantially higher than the cost of a 5-year option. In the case of Dell, for example, assuming that 
options are held to maturity would result in an option value of $\$ 17.15$ versus $\$ 13.04$ computed based on an assumed life of five years.

As a consequence, the FASB has realized that any option-valuation approach should permit use of an assumed life much shorter than the contractual life. The current guidance in SFAS No. 123 requires that option value be estimated over expected life rather than contractual life (the modified BlackScholes model) - five years in Dell's case. In terms of a binomial tree, Dell's option life assumption implies that all exercise occurs in the fifth year of the option life if the option is in the money and at no other time.

Unfortunately, that characterization is likely to be wrong for at least three reasons. First, even if option exercise occurs, on average, in the fifth year, it is likely to occur gradually over time rather than all at once. Second, when option exercise occurs, it is likely to be concentrated in certain regions of the binomial tree. For example, options that are deeper in the money may be more likely to be exercised early than those that are close to the money. Third, assuming an option life of 5 years ignores the fact that 10 -year options that are out of the money at 5 years still have value because they may move into the money in the last 5 years. But to say more, it is important to characterize employee exercise behavior in practice.

\section{Empirical Evidence}

Identifying patterns of employee option exercise behavior is difficult because data on option exercise are publicly available only at an aggregate level in the annual report. Huddart and Lang (1996), however, accessed a proprietary dataset of option exercise behavior for more than 50,000 employees at seven companies, with an eye toward understanding employee exercise behavior. They focused on four questions:

1. How pervasive is early exercise?

2. How predictable is early exercise?

3. What factors appear to explain early exercise?

4. Does early exercise vary across levels in the organization?

Huddart and Lang (1996) focused their analysis on risk aversion as a predictor of early exercise, much as Huddart (1994) had developed an analytical model predicting when exercise would occur under risk aversion. Huddart showed that risk-averse employees tend to exercise early and diversify when the value sacrificed by exercising early is relatively low and their degree of risk aversion is relatively high.

The results in Huddart and Lang (1996) indicate early exercise is pervasive. In their sample of companies, exercise typically occurred around the middle of the option lives, consistent with the Dell example. To assess the 
economic significance of the result, the authors estimated the amount sacrificed by early exercise, computed as the Black-Scholes value of the option, assuming exercise at expiration relative to the intrinsic value received through early exercise.

Employees commonly sacrifice as much as half of the theoretical BlackScholes value of the option by exercising early, suggesting significant risk aversion. Again, the notion that employees sacrifice significant value by exercising early is consistent with the Dell example, in which options held for their contractual life of 10 years are worth 31 percent more $(\$ 17.15)$ than options exercised after 5 years $(\$ 13.04)$. In some ways, this finding is not particularly surprising given that the typical employees are probably poorly diversified, with their fortunes tied closely to their employer, in terms of both company-specific human capital and investments in company stock through pension and employee stock ownership plans. Thus, faced with a choice, employees appear to opt to lay off some of that risk by exercising their options and diversifying.

In terms of exercise patterns, Huddart and Lang (1996) observed that when a given employee exercises, he or she typically exercises all available options at once (as opposed to gradually exercising), suggesting that employees may perceive some fixed cost to exercising that encourages them to wait until they are ready to exercise all their options. In terms of a given option grant to multiple employees, however, exercise tends to be spread out over time because individual employees exercise at different times, consistent with differences in risk aversion and liquidity needs. Thus, an implicit assumption (such as Dell's assumption that all exercise occurs in the fifth year) is not likely to reflect actual exercise patterns.

In terms of predictability, the timing of option exercise is variable across grants, adding noise to the process of estimating typical option life. For a company such as Dell, actual exercise experience on an individual grant basis is likely to deviate substantially from the five-year assumption. That result is not particularly surprising because, for example, cases in which stock price appreciation is limited after grant will naturally result in longer option lives.

The findings suggest that care should be taken when attempting to predict future option exercise behavior based on past behavior. The findings also suggest that option exercise assumptions can add a significant amount of noise to estimated option values.

To model the determinants of exercise more formally, Huddart and Lang (1996) estimated a regression of the percentage of a given grant exercised in a typical month on risk aversion variables expected to precipitate exercise. Huddart, for example, predicted that risk-averse employees will establish 
hurdles based on market/strike ratios because exercising options that are deep in the money sacrifices less value and permits employees to lay off more risk. In addition, he predicted that the market/strike ratio hurdle will gradually be lowered as the option moves closer to maturity so less value is sacrificed by exercising.

To avoid cases in which option exercise would not be economical, Huddart and Lang (1996) considered only options that were in the money by at least 15 percent. In terms of specific variables, they found the following.

Exercise is positively related to the market/strike ratio and negatively related to market/strike squared. Market/strike captures the notion that exercise will be higher the further the option is in the money because less is sacrificed when options are deep in the money (i.e., there is less downside protection) and the value of the option is very variable, moving almost in lockstep with the stock. Market/strike squared incorporates potential nonlinearity between market/strike and exercise. For example, moving from a market/strike of 1 to 2 is likely to have a larger effect on exercise than moving from 10 to 11 . Results suggest that exercise is generally increasing in the market/strike ratio but at a decreasing rate.

Exercise is positively related to elapsed option life. This finding follows from the notion in Huddart that the market/strike hurdle will drop as an option moves closer to expiration because the proportion of value sacrificed in early exercise decreases. As a consequence, companies with in-the-money options late in their lives are likely to experience increased exercise.

The preceding points are easy to see in the context of Dell's outstanding option grants. For example, Dell's 30 million options outstanding with a maturity of 3.49 years and a strike of $\$ 0.96$ are natural candidates for early exercise because the Black-Scholes value, if held to maturity, is $\$ 25.91$ and the intrinsic value is $\$ 25.84$. As a result, an employee with a portfolio of options seeking liquidity or risk reduction would naturally be drawn to those options because their value moves virtually dollar for dollar with share price and little of expected value would be lost through early exercise. The 41 million options with a remaining life of 9.02 years and a strike of $\$ 22.94$ tell a very different story. They will soon begin vesting and, based on a year-end share price of $\$ 26.80$, would be worth $\$ 3.86$ if exercised. But because they are close to the money with a long remaining life, their Black-Scholes value, if held to maturity, is $\$ 19.72$. As a result, it would take extreme risk aversion or liquidity needs to justify early exercise. An employee considering exercise for short-term liquidity needs would likely be better off exercising other options or borrowing money. 
Exercise is positively related to recent share price volatility. If employees are risk averse, periods of volatility will cause them to exercise options because volatility tends to persist (at least to some extent), so heightened past volatility suggests likely future volatility. A similar conclusion follows from Hemmer, Matsunaga, and Shevlin (1996), who found that option lives tend to be shorter for executives in companies with more volatile share prices.

Exercise is positively related to recent vesting. In the months immediately following vesting dates, exercise tends to be elevated because the vesting constraint has been binding for some employees who wished to exercise early in the option life. For example, in the case of companies with long vesting schedules, such as Dell, some employees may be so risk averse that they exercise as soon as they get a chance. Similarly, among options that are relatively deep in the money and about to vest, exercise will tend to be high following vesting.

Exercise is positively related to cancellations. Although cancellations may be at least partially outside the employee's control, one needs to recognize that a substantial portion of early exercise occurs because employees must typically exercise options within a stated period after leaving the company or they face having their options canceled. As a result, even in cases in which employees would choose to hold options to expiration given the opportunity, exercise will be higher following events precipitating employee terminations.

Exercise is positively related to recent share returns. Companies with recent stock price run-ups (during the exercise month and the 15 days leading up to the exercise month) are more likely to experience exercise. In terms of a model such as that offered by Huddart, such exercise is likely to occur because employees will typically have a market/strike trigger in mind based on their level of risk aversion, and positive recent returns can bring them to that trigger point. Alternatively, as discussed in Heath, Huddart, and Lang (1999), research in behavioral finance suggests that individuals are generally contrarian over the short term, believing that stock prices are mean reverting in the short term. As a result, they may exercise after a few days of stock price run-up to preserve the gains. ${ }^{2}$ Therefore, more exercise should be anticipated as shares increase in value.

Exercise is negatively related to longer-term share returns. Companies with longer-term share price increases (during days -15 to -60 relative to the exercise month) are less likely to experience exercise. Although this is a weaker effect than for the recent price run-up, the notion is that employees with in-the-money options who have experienced a general trend of increasing

2 It is important to note that the regression controls for the market/strike ratio, so the issue is whether, conditional on being in the money, the stock price path to the exercise month matters. 
prices will be less likely to exercise, perhaps out of a belief that the trend is likely to continue. As discussed in Heath, Huddart, and Lang, this belief is generally consistent with a finding in behavioral finance that individual investors behave as though longer-term trends are likely to persist.

According to Huddart and Lang (1996), employees' exercise behavior will differ depending on their level in the company, although the direction of the relationship is not necessarily clear. For example, on the one hand, higherlevel employees generally have a higher proportion of their compensation linked to the performance of the company, thus increasing their sensitivity to company performance. On the other hand, they may also have more outside wealth and thus have less need to exercise options in order to achieve diversification. Furthermore, given their visibility in the company, they may perceive greater pressure to refrain from early exercise. As an empirical matter, the evidence offered by Huddart and Lang (1996) suggests that lowerlevel employees behave as though they are more sensitive to risk aversion than are more senior employees and are more likely to exercise early.

Heath, Huddart, and Lang used the same data as Huddart and Lang (1996) to examine the effects of behavioral factors related to past stock price paths on the exercise decision. They argued that employees may respond to behavioral cues in decision making and focused on the possibility that employees may use past stock price extremes as reference points in making exercise decisions. Such behavior seems more likely to occur in broad-based option plans because lower-level employees may be financially unsophisticated and might be tempted to trade on such cues as past stock price extremes.

Exercise is elevated when share price exceeds the 52-week high. This result is striking because it suggests that beyond simple economic explanations, behavioral factors also appear important in employee exercise decisions. Core and Guay (2001) reached the same conclusion for a much larger sample of companies with broad-based option plans. In terms of predicting future option exercise, the results suggest that periods when stocks are at unusually high levels will precipitate more exercise.

Heath, Huddart, and Lang focused on price relative to the 52-week high, although they considered other measures as well. Little evidence indicates that current share price relative to the 52 -week high predicts future returns, but the 52 -week high is a statistic that is frequently mentioned in the press and may seem relevant to some employees.

Finally, Huddart and Lang (2003) examined whether employee option exercise decisions are predictive of future returns. Although a substantial body of research on executive trading decisions and future returns exists, most of the evidence is based on U.S. SEC filings of insider trading, including 
sales of stock, and the evidence is mixed. Option exercise in broad-based plans has received less attention because lower-level employees are not required to file with the SEC when they exercise options. Huddart and Lang (2003) examined employee exercise decisions and future stock returns across all levels of employees in stock option plans.

Exercise is negatively related to future returns. This result is interesting because it suggests that employees may, on average, have foreknowledge of a company's general prospects and are more likely to exercise prior to negative returns. Because most employees exercise and cash out immediately, the evidence indicates that employees appear to trade to take advantage of private information about the company's prospects. Furthermore, the return predictability is not concentrated in the weeks immediately following the exercise decision but extends for as long as three months, suggesting that employees are not responding to an imminent news release but to general knowledge of the company's prospects.

Interestingly, the relationship between exercise and future returns extends to employees deep in the organization, suggesting fairly pervasive information-based trading. Unfortunately, the publicly available data on option exercise for broad-based plans are too aggregated and not timely enough to be used to predict returns in practice.

\section{Implications}

The research on employee exercise decisions offers a number of valuable implications. Consider, for example, the 49 million options with a weightedaverage exercise price of $\$ 44.69$ and 7.89 years remaining in Dell's footnote for 2002. My previous discussion assumed that these options should be valued with the assumption that exercise will occur in 3.95 years. But with share prices in the high $\$ 20$ s to low $\$ 30$ s, the odds of the options being sufficiently in the money to justify exercise in three years are fairly low. Even if the options move into the money, the research results suggest that option exercise may remain low until the options move substantially into the money. As a consequence, an expected life closer to the contractual life may have merit.

For Dell's options that are deep in the money, however, early exercise is likelier because little value is sacrificed relative to the risk that can be diversified away by reinvesting the proceeds in a broader set of assets. In particular, in cases in which options are deep in the money and the stock is trading near a 52-week high, exercise is likely to be more pronounced. Companies facing periods of increased share price volatility are also likely to experience increased exercise, as are companies that have made large grants that are vesting. Although no simple formula exists for incorporating these factors into the exercise forecast, it is important to keep them in mind. 


\section{Option-Valuation Models}

One of the most controversial aspects of stock options is determining the appropriate option-valuation model. Although several issues surround applying standard option-valuation approaches to employee stock options, probably the most vexing is the issue of early exercise assumptions because, as the preceding section illustrates, option exercise is a function of many factors and belies simple assumptions.

Modified Black-Scholes Model. Early exercise based on expected option life is explicitly incorporated in the modified Black-Scholes model presented in SFAS No. 123. But that approach assumes that all exercise occurs in the average exercise year. Dell indicates that it applies the modified BlackScholes model. It assumes that expected life is five years, the risk-free rate is 4.63 percent, volatility is 61.18 percent, and there are no dividends. Entering those parameters into the modified Black-Scholes model yields the reported option value of $\$ 13.04$.

But the empirical research on option exercise suggests that the modified Black-Scholes assumptions are likely to be violated in several ways. First, option exercise for a given grant is typically spread out over several years rather than occurring at one time. If the relationship between option value and expected life were linear, using the average expected option term for valuing employee options would not pose a problem. But option value is convex in option life, so replacing the exercise life with the expected life understates the value of the options relative to valuing various option life groupings separately and adding the values of the groupings together to compute total option value. The extent of the inaccurate pricing depends on the clustering of exercise in practice. Research such as that conducted by Huddart and Lang (1996) suggests exercise is spread out over the life of the option, with exercise typically starting as soon as options vest and continuing until the options expire, rather than clustering in any particular month.

A decision to ignore that fact and assume that exercise is clustered in a particular year potentially biases the option-valuation estimate. Hemmer, Matsunaga, and Shevlin (1994) discussed the implications of ignoring variation in option exercise. Their argument is very straightforward. If option exercise is spread out over time, a more accurate result will be obtained if gradual option exercise is explicitly incorporated in valuation. For example, Dell's assumption that all exercise takes place at the end of Year 5 yields a Black-Scholes value of $\$ 13.04$. If, however, one assumes that option exercise is spread out over the option life and occurs every six months beginning at the end of Year 1 and ending at the end of Year 9, the average life remains five years but the value of the average option drops to $\$ 12.43$. Because option 
exercise is spread out in practice, option valuation based on a range of exercise lives is probably more accurate. Furthermore, computing the option value based on an assumption that option exercise is spread out over time is not a complicated matter.

Huddart Model. Although the approach of Hemmer, Matsunaga, and Shevlin (1994) incorporates a spread of exercise over time, it assumes that exercise is not affected by how far the option is in the money. In practice, however, exercise is indeed correlated with how far the option is in the money. As discussed in Kulatilaka and Marcus (1994), dealing with the convexity of option value with respect to option life is relatively straightforward, but addressing the possibility that exercise is correlated with share price is potentially more important and more complex. The Huddart model explicitly incorporates risk aversion and predicts that option exercise will be more prevalent when options are further in the money.

Employees are typically more willing to exercise options that are deep in the money and close to the end of their lives because the proportion of the value sacrificed by early exercise (based on the ratio of the Black-Scholes value to intrinsic value) is relatively low, so the benefit from exercising early and diversifying exceeds the sacrificed value. As a result, Huddart predicted that employees will establish a target market/strike for exercising and will exercise when stock price exceeds that threshold. Furthermore, the threshold market/strike will decrease over time as the remaining life of the option decreases. That finding is important because it violates the assumption, under SFAS No. 123, that early exercise will cluster at the expected life. But if early exercise is precipitated by the kinds of factors that Huddart anticipates, it will be spread out over time for a given company depending on its past stock price path and remaining time to expiration. That prediction is also generally consistent with the empirical evidence that exercise is increasing in the market/strike ratio and decreasing in the remaining option life.

In terms of option valuation, Huddart investigated whether the modified Black-Scholes approach systematically overvalues options when compared with an approach that explicitly takes into account early exercise precipitated by risk aversion. His model suggests that ignoring the determinants of exercise, as the modified Black-Scholes model does, can overstate option value, although the precise amount is complicated because it is a function of the extent of risk aversion and the terms of the option. Although his approach is more difficult to implement in practice, Huddart showed that options can be overvalued by as much as 10-20 percent if the clustering of exercise at high market/strike ratios is ignored.

Investigating the Models. Other assumptions about exercise can yield different implications. For example, if employee separations are correlated 
with past share price movements, exercise may be more common in certain regions of the binomial tree. If employees typically cash out and leave when the company is performing well, early exercise will occur at high market/ strike ratios. Alternatively, employees might be laid off when the company is performing poorly, thereby increasing option exercises or forfeitures at low market/strike ratios.

The difficulty in accurately predicting exercise causes some critics to argue that values for employee stock options cannot be reliably measured and, therefore, should not be expensed. But because some of the effects noted would cause the modified Black-Scholes model to overvalue options and others to undervalue them, the extent to which option value estimates would be biased in practice is not clear.

Marquardt (2002) investigated that issue by directly comparing the ex ante expected cost of options with the ex post cost for a sample of 966 option grants over the period 1963-1984. She compared option valuation under the modified Black-Scholes model in SFAS No. 123, adjusted for convexity, with the average ex post cost of the same options based on their actual payouts. Her results provide several insights. First, the option-pricing models estimate $e x$ post value with a great deal of noise. That finding is not surprising given that the variability of share prices implies a wide range of potential outcomes so that any estimate of expected value will tend to estimate realized future value with substantial error, especially for volatile stocks. More importantly, however, the modified Black-Scholes model appears to value options without substantial bias, which suggests that, although it ignores theoretically important considerations, such as risk aversion, the implications for the resulting value are rather limited (at least relative to the inherent noise in estimating option values).

Carpenter (1998) conducted a similar analysis of 40 companies using option exercise behavior. She compared models such as Huddart, which explicitly considers risk tolerance, with a simpler model that assumes random exogenous exercise and forfeiture and also with the FASB's modified BlackScholes model. She found that the simpler models perform nearly as well as the more complex models that explicitly incorporate risk tolerances.

The results on model specification are particularly interesting because much of the debate over expensing options focuses on the inability to arrive at a generally accepted, theoretically correct model for valuing options. Although the research points out potential shortcomings in the modified Black-Scholes model, the improvements gained by applying more-complex models are generally modest. More importantly, it is not clear that the modified Black-Scholes model systematically undervalues or overvalues 
options. Although it measures the ultimate realized value with a great deal of error, such a flaw is inherent in the process of forecasting the outcome from a volatile series.

Because the FASB recognizes the difficulty in valuing options and concerns regarding the modified Black-Scholes model, its current proposal would allow companies to adopt more-complex approaches that could provide more-accurate value estimates. For example, a binomial pricing model could be used because it permits specific assumptions about the nodes where exercise occurs. Although the calculation is more cumbersome than the Black-Scholes model, a binomial pricing model allows for a variety of assumptions about exercise timing.

Potential for Bias in the Models. Besides identifying an appropriate option-valuation model, one must also investigate whether different choices of method or inputs might bias the resulting option expense. The temptation to bias the option calculation might be particularly attractive to companies because the value is generally not "trued up" to reflect changes that may have occurred in the interim. ${ }^{3}$ Most assumptions in accounting are adjusted when information on outcomes becomes available, meaning that any bias in assumptions will ultimately be undone. But underestimating an input such as option life would reduce option expense initially without directly affecting future expenses. 4

The calculation of option expense could be manipulated in at least two ways. First, the company might choose an option-valuation method that gives a lower expense. SFAS No. 123 gives some latitude among option-valuation approaches based on the binomial model. So, for example, a company seeking lower compensation expense might adopt the approach suggested in Hemmer, Matsunaga, and Shevlin (1994) to correct for the effect of convexity on option values or the approach suggested in Huddart to correct for the fact that employees tend to exercise when options are deep in the money. An attraction of those approaches is that they generally provide a lower but more accurate measure of option expense and are, therefore, permissible. But they potentially reduce comparability across companies. Given the fact that a company

3 An exception is the estimate of options to be forfeited during vesting, which is adjusted for actual experience.

4 The exposure draft on SFAS No. 123 had a provision that would have required adjustments to option expense if the option life were estimated inaccurately. But that provision was dropped because it would have had the perverse effect of resulting in a greater expense for options that were out of the money for most of their lives and only moved into the money near their expiration. Although those options would have had a long life, they would represent little cost to the company because they would probably not be deep in the money at exercise. 
must disclose its option assumptions, computing the option expense under a modified Black-Scholes model would be simple enough and would allow for consistency across companies.

Considering determinants of option expense for companies in the S\&P 500 Index, MidCap 400 Index, and SmallCap 600 Index, Aboody, Barth, and Kasznik (2003) suggested that companies rarely use approaches other than the modified Black-Scholes model. But if requirements were to change to mandate income statement recognition, the incentives to adopt alternate option-valuation approaches might well increase.

Second, and more troubling, is the potential that the inputs to the models might be manipulated to reduce the amount of option expense in the pro forma disclosure, which would also reduce the usefulness of the disclosed assumptions for creating one's own estimate of option expense or the value of outstanding options. For example, using a lower assumed risk-free rate, lower volatility, greater dividend payout, or shorter life would reduce the implied cost of the options.

The interest rate assumption is difficult to manipulate because it is specified as the implied yield currently available on zero-coupon U.S. government issues with a remaining life equal to the expected option life. Volatility, however, which is based on the most recent period that is commensurate with expected option life, can be modified if current information indicates the future is reasonably expected to differ from the past. Similarly, dividend yields should consider historical dividend policy and the likelihood of changes in dividends over the expected option life. As a result, volatility and dividend policy are subject to some discretion and could potentially be manipulated by arguing, for example, that volatility had been unusually high and was likely to drop or that the company was likely to increase dividends in the future.

Aboody, Barth, and Kasznik (2003) examined the assumptions on interest rates, dividend yield, and volatility for their sample of companies during the 1996-98 period and found no evidence that their assumptions were biased to reduce reported option cost. That finding is probably not surprising given the ease with which these option assumptions can be validated.

Expected option life is probably the most likely input to be manipulated because option value is fairly sensitive to option life and most companies do not have long histories over which to estimate average lives. For example, the value of Dell's 2002 options drop from $\$ 13.04$ to $\$ 10.33$ if the assumed expected life is reduced from five to three years. Furthermore, there is no disclosure comparing past realized option lives with estimates, so it is difficult to document ex post that expected lives were biased. As Huddart and Lang (1996) documented, realized option lives vary substantially from grant to grant 
depending on factors such as the past stock price movement. As a result, it is not unusual to see some grants that quickly move deep into the money and experience substantial exercise around vesting dates and others that remain near or out of the money for most of their lives and experience very long lives.

In theory, expected option life should be determined based on "normal" exercise. But companies seldom experience "normal" stock price paths (especially because options are typically long lived and are a relatively recent phenomenon). As a result, knowing how to estimate option life even for a company acting in good faith is difficult. But to the extent that companies initially relied on experience during the bull market of the 1990s to estimate option lives, one might expect that option life assumptions will increase in the next few years as companies experience less early exercise because of lower stock prices. As a result, the amount of pro forma option expense could well increase simply because of decreased early exercise resulting from lower stock prices.

Aboody, Barth, and Kasznik (2003) examined option life assumptions for their sample companies. But the analysis is limited because, unlike volatility and dividend policy, they did not have historic values with which to compare assumptions (a problem that would be shared by an investor attempting to ascertain the accuracy of reported expected life assumptions). As a result, they investigated whether reported expected lives tend to be systematically shorter in cases where companies may have the greatest incentives to report lower option costs. In particular, they argued that companies that are more committed to the use of options and have higher-paid CEOs will have greater incentives to understate expected lives and, hence, option costs. They found, however, little evidence that such behavior occurs. Unfortunately, the tests were relatively weak because of the difficulty in establishing the appropriate assumed option life.

Although the existing evidence provides some assurance that companies do not systematically bias assumptions, incentives may increase if options are expensed. By their very nature, interest rates, volatility, and dividend policy are easier to verify and, therefore, less subject to abuse. Expected option life, in contrast, is subject to estimation error, intentional and otherwise. Therefore, it may be useful to compare option life assumptions across companies for reasonableness. If the comparisons show that a company's assumptions appear to be unreasonably low, the option value can be recalculated using an alternate life assumption.

Probably the single most important determinant of option life is the expected stock price path, which should be approximately the same across similar companies. But lives might be expected to differ across companies based on share price volatility and differences in expected turnover. Option 
lives should be similar for companies with similar expected volatility (based on, for example, age of the companies, industry, and past stock price volatility). All else being equal, one might expect more early exercise among riskier companies as employees attempt to reduce risk. Furthermore, riskier companies will probably experience more cancellations resulting from greater turnover, such as layoffs and voluntary departures. More volatile companies, however, may attract more risk-tolerant employees, thus mitigating the effect of risk on option exercise. As a general rule, though, it seems reasonable to expect similar option life assumptions for companies in similar industries with similar volatility. 


\section{Option Value to Employees}

As noted earlier, an important result of providing options is that many employees end up with poorly diversified portfolios, which means that they are exposed to a good deal more risk than they would like. Left to their own devices, risk-averse employees with substantial option compensation would probably prefer to lay off that risk by selling or hedging some or all of their options. Typically, however, employees are not given the opportunity to sell their options and are prohibited from hedging with tactics such as shorting the employer's stock. As a result, the choice is between holding a risky investment and sacrificing the investment's upside potential by exercising the options early.

\section{Employee Risk Aversion vs. Incentive Effects}

The inability to lay off risk is crucial because it is the risk that creates the incentive effects. If employees were permitted to sell their options, the option's value to employees would increase, but the incentive value for the company would be lost because once the options were sold, the employees would have no stake in the company's share price performance. Hedging has a similar effect. If employees could short the stock, the incentive properties would be sacrificed because the share price exposure would be gone.

This wedge between the theoretical value of options and their perceived value to employees represents a sort of deadweight loss, potentially made up by the incentive effects of options. To the extent that the incentive effects do not justify the deadweight loss, options are not optimal. This concern is particularly relevant in the case of broad-based option plans because strong incentive effects for lower-level employees are less plausible. For example, would a midlevel manager holding a small number of options in a large company work significantly harder in hopes of increasing share price given that his or her share of the value increment would be very small?

The notion that the value of the option to the employee can deviate from its cost to the company yields several paradoxical observations. For example, an option with no vesting requirements costs the company less in expectation because employees will, on average, exercise earlier. But it is of higher value to the employees because it is less restrictive and permits them more flexibility. As a result, the cost to the company could be reduced and the benefit to the employees could be increased by removing vesting requirements and thus 
reducing the deadweight cost of the option. Offsetting that benefit, however, is the loss of incentive and retention benefits if employees are permitted to exercise early. If, in contrast, the company were to extend vesting (or even preclude early exercise entirely), it would improve the incentive and retention benefits, but it would do so at the cost of reducing the value of options to employees and increasing their cost to the company.

\section{Volatility and Employee Options}

The effect of volatility on employee stock options is also complicated by risk aversion. For a traded option, increased volatility raises option value because it increases the upside of the option to the holder while the downside is truncated. But for employee stock options, the effect of volatility on the cost to the company is less clear because of the effect of risk aversion. For example, Huddart and Lang (1996) and Hemmer, Matsunaga, and Shevin (1996) found that increased volatility tends to be associated with increased early exercise, which suggests the effects of risk aversion. But volatility and early exercise have different effects on the cost of the option to the company: Early exercise tends to decrease the cost of the option to the company, and increased volatility during the period that the option is outstanding tends to increase the cost of the option to the company. Similarly, increased volatility increases the risk of option compensation, which employees would prefer to avoid, but volatility in the stock price also increases the expected payoff to the option. Thus, an employee with options in a volatile company is trading off the greater expected value associated with options against the greater discount applied to that compensation because of its risk.

Hall and Murphy (2002) estimated the likely effect of risk aversion on option exercise and value to employees. They argued that, under reasonable risk aversion and diversification assumptions, substantial early exercise can be optimal from the employee's perspective. They also found that, as a result, the value of an option to a risk-averse employee can be as little as 21 percent of its theoretical cost to the company using an assumed option life equal to the 10 -year contractual life. Because options are typically exercised early, the cost to the company is reduced. But even taking into account optimal early exercise under risk aversion, the value of the option to the employee can be worth as little as 63 percent of the modified Black-Scholes cost to the company.

Meulbroek (2001) made a similar attempt to assess the efficiency loss of forcing employees to hold an undiversified portfolio with a concentrated exposure to their employer's stock. She estimated that managers at an NYSElisted company with all of their assets tied to stock price would value typical options (10-year life and 3-year vest) at 70 percent of their cost to the employer. 
The figure is more striking for Internet companies, where volatility is higher. Meulbroek estimated that undiversified managers in such companies value options at 53 percent of their cost to the company. By changing her assumptions about the degree of employees' diversification, Meulbroek found that her results changed somewhat. For example, by assuming that Internet company managers hold 50 percent of their wealth outside the company, option value increases to 59 percent of cost. Even so, the gap is still striking.

Although the value perceived by the employee may differ from the cost calculated under the modified Black-Scholes model, the relevant consideration from an equity valuation perspective is the cost to the company. After all, such employee perceptions are not directly relevant to equity valuation. Nevertheless, they can be indicators of the efficiency of options as an incentive device, especially for broad-based option plans. For example, if a company has to pay 30 percent more in option value than it would in cash, the incentive effects have to be very substantial to justify the added cost.

Although large incentive benefits are plausible for high-ranking executives, they seem less likely for lower-level employees, who may correctly perceive that their effort has little effect on stock price. Furthermore, lowerlevel employees tend to be more risk averse and have less outside wealth than executives, so they may place more of a discount on option compensation. Results in Huddart and Lang (1996) suggest that the exercise decisions of lower-level employees demonstrate that they are more risk averse than higher-level employees.

The fact that options may be worth less to risk-averse employees has several important implications for equity valuation. First, as noted earlier, if option intensity is estimated inaccurately going forward, other compensation should substitute for stock options. But to the extent that employees are risk averse, the degree of correspondence may be less than dollar for dollar. As a result, a company that increases option intensity more than expected may face higher than expected total compensation costs because it has switched to a more costly mode of compensation. Similarly, if a change in accounting to require expensing were to reduce option use, the accounting change could actually reduce total compensation costs for companies by causing them to substitute lower-cost compensation for higher-cost options.

\section{Incentive Benefits vs. Accounting Benefits of Options}

But why would companies issue options if the cost exceeded their incentive benefits? One possibility is that some companies' decisions are driven by accounting considerations. In particular, options are the primary means by which companies can compensate employees without expense recognition on 
the income statement. Although the information necessary to estimate the cost of options is available in the footnotes, companies may view options as less expensive in an accounting sense because they do not affect profitability on the income statement, either at the time of grant or when exercised.

Hall and Murphy (2002) argued compellingly that the popularity of option compensation (especially for lower-level employees) is consistent with the notion that companies perceive the cost of options to be lower because of their favorable accounting treatment. In particular, they argued that other potential explanations for broad-based option plans appear inconsistent with their prevalence. For example, options impose significant risk on employees who are unlikely to be particularly risk tolerant and who must, therefore, be paid significantly more in expectation to compensate them for the added risk. Furthermore, as research seems to indicate, lower-level employees do not seem to perceive much of an incentive effect from their ability to influence compensation through the effect of their activities on stock price. Nor can one argue convincingly for employee retention as a goal for option plans. After all, designing other forms of compensation that achieve similar goals at lower cost is easy. Even for cash-poor companies, options seem a questionable tool because such companies are, in effect, borrowing from employees, which is unlikely to be the most efficient form of financing. Finally, the notion that companies view option expensing as a major concern is consistent with their lobbying activity in response to SFAS No. 123 and recent proposals to expense options.

The general design of stock option plans reinforces the importance of accounting treatment. In particular, the vast majority of options (Dell's among them) are granted at the money with fixed terms. It seems unlikely that the prevalence of that choice of strike price is designed to optimize the incentive effect of options. Rather, the incentive and risk characteristics of options could more likely be improved if, for example, options were issued in the money or payoffs were tied to share price relative to other companies in the industry. But under current accounting, in-the-money options and options with terms tied to future performance require expense recognition, and those types of options are rare.

\section{Accounting, Compensation Design, and Repricing}

Empirical evidence of the effect of accounting treatment on compensation design can be gleaned from companies' behavior with respect to repricings. With a typical repricing, an option that has fallen deep out of the money is "repriced" by reducing the exercise price to one that is closer to current market price. The most common reason given is that the option has lost its incentive effect if it is far out of the money because the sensitivity of option value to share 
price decreases the farther an option is out of the money. A common counterargument is that the knowledge that a company will reprice an option if it falls far enough out of the money reduces incentives to avoid large share price drops and may even encourage managers to permit temporary price drops by, for example, withholding good news so that the option is repriced at a more easily attained level. But research by Acharya, John, and Sundaram (2000) suggests that repricings may be economically efficient, even considering the initial incentive effects, because they permit incentive realignment.

In December 1998, the FASB changed the accounting for option repricing, requiring that companies recognize an expense based on the change in strike price if options were repriced. But the FASB offered a short window before the change went into effect. Carter and Lynch (2003) examined companies' reactions to the accounting change. In particular, they documented a pronounced spike of repricing during the window of opportunity, apparently reflecting a rush by companies to avoid an expense for repricing. After the change went into effect, repricings virtually disappeared.

Looking over a longer horizon, Murphy (2003) also documented that repricings have virtually disappeared since the accounting change. He found that, in 1997 (prior to the accounting change), 29.2 percent of the new economy companies and 11.5 percent of the old economy companies that had experienced a stock price drop of at least 50 percent during the previous 24 months repriced options. In 2000, that number had dropped to 1.4 percent for the new economy companies and 0.6 percent for the old economy companies, reflecting, apparently, the change in accounting.

Murphy also suggested that the change in accounting caused companies to consider other approaches to achieve incentive realignment without sacrificing the desired accounting treatment. For example, one approach is to cancel an option deep out of the money and issue a new option at the money. But the U.S. SEC anticipated that possibility and issued requirements that canceled options could not be reissued for six months. As a result, some companies began issuing "six plus one" options, which are issued six months and one day after the cancellation, suggesting yet another attempt to avoid expense recognition.

Although the preceding discussion is limited to the context of repricings, it suggests the power of accounting to influence compensation design in the context of options and implies the possibility that option intensity and structure might change substantially when the FASB and IASB require option expensing. Companies are unlikely to do away with options entirely, but they may be less likely to use them in contexts where the rationale behind granting options is less compelling, such as for broad-based plans. 
If all forms of compensation are accorded similar accounting treatment, it seems likely that companies will, at least to some extent, substitute other forms of compensation for employee stock options. Already some companies have indicated an intention to substitute restricted stock for options. Because a given fair value of restricted stock is less risky than the same fair value of atthe-money options, companies may be able to substitute less than a dollar of restricted stock for a dollar of the modified Black-Scholes value of options. As a result, the overall cost of compensation could decrease. Potentially offsetting this benefit, however, would be a reduction in the incentive effect. After all, the risk of at-the-money options reflects their power to provide incentive: A given increase in share price has a greater effect on the value of a portfolio of at-the-money options than it does on the value of an equivalent portfolio of restricted stock. 


\section{Impact on Cash Flow and Valuation}

The preceding chapters discuss research on basic issues in valuing equity for companies with employee stock options. In this chapter, I consider research on a variety of other topics with implications for equity valuation.

\section{Determinants of Option Grants}

One of the difficulties in incorporating future option grants into equity valuation is estimating expected option intensity. At the start of this monograph, I estimated the effect of future options separately from operating cash flows, reflecting an assumption that the starting point was operating cash flows, excluding options-a reasonable assumption if the starting point for the cash flow forecast is reported earnings, ignoring options. An alternative approach, however, is to subtract expected option expense from each year's net income and explicitly forecast profitability after the effect of options. Because the future value of options is being present-valued under both approaches, they should yield similar answers. Assuming that the FASB and IASB ultimately require stock option expensing (and analysts forecast reported net income), future option grants will be incorporated more naturally in equity valuation.

Even if options are expensed, however, future option grants will still need to be estimated in arriving at earnings forecasts. One way to incorporate options would be to forecast total compensation under the assumption that the components of compensation are less important than the whole. But that approach assumes that the mix of compensation does not change or, if it does, that employees value options at their modified Black-Scholes value so that different forms of compensation can be substituted dollar for dollar. If, for example, a smaller amount of cash can substitute for a larger Black-Scholes value of options, then a shift in the components of compensation could affect total compensation. Furthermore, the change in components could affect incentives and, hence, other cash flows.

One of the few studies to examine future option grants for broad-based plans was done by Core and Guay (2001), who studied the determinants of option grants for a large sample of companies and found that grants tend to be higher for companies with cash constraints, high capital needs, and high cost of accessing capital markets. They also found that option grants tend to be higher in years when returns are high and in years following large option exercises. 
The finding that exercise might precipitate more grants seems consistent with the notion of a target incentive level. Under that scenario, exercising options would reduce incentives, so companies might issue more options to replenish them. As a consequence, it may be useful to link assumptions about grants to the assumptions about exercise discussed earlier. The other factors are a bit more difficult to incorporate because the evidence is primarily crosssectional. But if similar incentives hold over time, companies would be expected to issue more options (all else being equal) when faced with cash shortfalls and capital constraints. Companies with tax losses may issue more options to defer the tax deduction to later periods of higher profits.

Forecasting option grants is also difficult because companies are still apparently experimenting to determine optimal option levels. Similarly, changes in accounting treatment and stock market trends could have significant effects on option usage. As a consequence, the best approach for dealing with options-barring a reason to believe that option intensity will change substantially - may be to focus on total compensation and assume that option compensation grows at the same rate as other compensation. Even then, the assumption matters to equity valuation only if other compensation does not substitute for errors in the estimate of option compensation.

\section{Options, Repurchases, Dilution, and Cash Flow}

One potentially interesting issue to consider from a cash flow perspective is the link between option repurchases to avoid dilution and future cash flows. In the initial equity valuation discussion, I assumed that companies repurchase options to satisfy option exercise and argued that in an efficient market the decision to repurchase should not affect company value as long as the cash used to repurchase shares would otherwise fund zero-net-present-value projects. But for an option-intensive company with an appreciated share price, the implications of options for future cash flows can be substantial.

Although a company need not buy back shares to offset option exercise, substantial evidence indicates that many do. Bens, Nagar, and Wong (2002), for example, examined whether companies tend to repurchase shares to satisfy option exercise and, if so, whether the repurchases appear to come at the expense of other investment activity. They provided evidence that for the S\&P 500 in 1999, repurchases tended to be higher for companies with more stock option exercise (after controlling for other factors) and confirmed that optionintensive companies generally repurchase shares. Their evidence also suggests that companies repurchasing shares to satisfy option exercise tend to have reduced R\&D investment and capital expenditures and generally underperform, which they interpret as evidence that the desire to repurchase shares may cause managers to sacrifice even positive-net-present-value projects. 
Although their evidence is potentially interesting, it is unclear why companies would be so keen to repurchase shares. One argument is that companies repurchase to avoid the dilution with option exercise, perhaps in an attempt to bolster EPS. Although repurchasing shares reduces the denominator in the EPS calculation, it also affects the numerator by reducing profits if the cash used to repurchase was otherwise tied up in productive uses. Whether the net effect is an increase or decrease in EPS depends on how profitably the cash used to repurchase would otherwise have been employed. Furthermore, even if managers are keen to repurchase shares, it seems surprising that they would do so at the expense of investment rather than, for example, borrowing money to fund the repurchases. But whether or not the repurchase of shares is efficient, the important conclusion is that significant cash flow implications exist for companies that repurchase shares to satisfy option exercise.

\section{Options and Incentives}

Most of the discussion to this point has effectively ignored the incentive effects of options by assuming that incentives are captured in the free cash flow forecasts. For practical purposes, knowing how to factor in the incentive features of options is much more difficult. But given the centrality of option incentives, at least considering their potential implications for operating cash flows is important because if there were no incentive effects, option-based compensation would probably not be optimal.

For a company with a fairly stable option compensation policy, incorporating incentive effects is probably less important because past experience (demonstrated by sales growth rates and profitability) already reflects the effects of options. Similarly, because those effects are already reflected on the income statement, they will naturally flow through to earnings forecasts.

But if a company has recently changed its compensation structure or is anticipated to do so in the future, the past may be less representative of the future. To understand the incentive effects of options, consider again the formula for option value. Some of the incentive effects are clear. For example, as share price increases, so does the value of options. As a result, options should encourage employees to build the company's value. Unfortunately, researching the performance incentive effects of options is difficult because of the challenge in controlling for other potential determinants of performance. In addition, establishing a causal link between option intensity and performance is difficult because companies choose their compensation mix, and option intensity itself may be influenced by performance. For example, an observed positive association between performance and option intensity could 
occur because options create incentives to improve performance or because high-performing companies are more likely to pay in options to attract top executives.

One article that attempts to link stock option intensity to future earnings is Hanlon, Rajgopal, and Shevlin (2003). Using a sample of 1,069 companies from 1997 to 2000, they considered the relationship between the previous five years of option grants to the top five executives and future earnings. They found that additional option-based compensation is associated with higher future operating income, which is consistent with options providing incentives to increase profitability. Furthermore, they found little evidence that option intensity is correlated with governance issues, which is inconsistent with the notion that executives are exploiting poor governance to increase their compensation. Rather, option grants appear to be largest when the incentive properties of options would be most important. As found in Hanlon, Rajgopal, and Shevlin, the evidence seems to indicate that option intensity is determined by economic considerations rather than the self-interested behavior of managers. Unfortunately, other evidence contradicts their findings. For example, Core, Holthausen, and Larcker (1999) examined a different sample and time period and found evidence that executives of companies with poor governance may, indeed, extract greater compensation and that companies with greater agency problems perform poorly.

Less obvious are the other incentive effects of options. For example, because options are not typically dividend protected, option value is lower if the company pays dividends. Therefore, options create incentives for companies to repurchase shares with excess cash rather than to pay dividends because dividends reduce share price when the stock goes ex dividend. Some research (see Lambert, Lanen, and Larcker 1989) indicates that companies tend to reduce dividend payouts after initiating their option plans.

Furthermore, options may affect managers' willingness to take on risk. On the one hand, because option value increases with stock price volatility, an option plan can encourage managers to take on risk. On the other hand, because risk also increases with stock price volatility, an option plan can discourage managers from taking on risk. Which effect dominates depends on the risk aversion of the manager and the particular characteristics of the options. Research by Rajgopal and Shevlin (2002) suggests that option-based incentives encourage managers in the oil and gas industry to take on risky projects.

In addition, options may increase retention and attract particular types of employees. For example, research by Ittner, Lambert, and Larcker (2003) indicates that employee retention is a primary motivation for option issuance to lower-level employees, particularly in new economy companies. But as 
pointed out in Hall and Murphy (2003), if retention is a primary goal, alternate compensation devices could encourage retention without imposing as much risk on employees. Similarly, options may be useful in attracting employees who are more risk tolerant, which may explain the prevalence of options among young, high-growth companies.

More directly, options create incentives to maximize the gap between the market and strike prices at exercise. Although that result might be achieved by increasing company value, it also creates incentives to manipulate the market or strike price. For example, a manager might attempt to reduce the strike price by decreasing share price shortly before an option grant. Aboody and Kasznik (2000), for example, documented that managers appear to withhold good news until after option grants to take advantage of the increase in share price. Similarly, a common assertion is that part of the reason for the increase in earnings restatements in recent years has been the prevalence of stock-based compensation. But although many notable examples exist of fraud at option-intensive companies, the majority of option-intensive companies have not been the subject of fraud allegations. The results of research on the relationship between option compensation and the incidence of accounting fraud and restatements-see Erickson, Hanlon, and Maydew (2003)—are mixed at best. One cannot assume, therefore, that a company is more likely to manipulate its earnings simply because it issues more options.

It is difficult to know how best to incorporate the potential incentive effects of options in equity valuation. Explicitly considering the incentive effects is probably less important if a company has a stable compensation policy because the effects of options will be reflected in past experience. But if the company has significantly changed its compensation policy recently or is expected to do so in the near future, such a change could affect the time series of expected future operating cash flows.

\section{Options and Dilution}

Employee stock options represent a competing claim against the equity of a company. Diluted EPS is an attempt to capture the dilutive effect of options and other securities on the claims of existing shareholders. In particular, current accounting differentiates between basic and diluted EPS, with options taken into account in the diluted EPS calculation, which uses the treasury stock method to deal with options.

In this method, the company computes the number of options that are in the money at the end of the year as a basis for dilution. But rather than simply adding those shares to the number of shares outstanding, an adjustment is made for the cash that would be received (the strike price) if the options were 
exercised. Essentially, the dilution factor for the adjustment is based on 1 minus the strike/market ratio. For example, consider a company with 100 options outstanding, a strike price of $\$ 10$, and a current market price of $\$ 40$. If the options were exercised, the company would receive $\$ 1,000$ and 100 more shares would be outstanding. The company would then use the $\$ 1,000$ to repurchase 25 shares $(\$ 1,000 / \$ 40=25)$. As a result, although 100 options were outstanding, the dilution would be based on the 75 shares that could not be repurchased with the proceeds from the option exercise.

This approach has the advantage of explicitly taking into account the extra shares outstanding after options have been exercised as well as the potential use of the proceeds, but it ignores taxes when computing the number of shares to be repurchased. When employees exercise nonqualified stock options (NQOs), the company receives the proceeds plus a tax deduction based on the intrinsic value at exercise. So, conceptually, the cash available to repurchase would be the following:

Strike price $+[$ Tax rate $\times($ Market price - Strike price $)]$.

The proportion of exercised shares repurchased would be that quantity divided by the price per share.

Continuing the example above and assuming a 35 percent tax rate, the cash available for repurchase would be $\$ 2,050$, computed as

$$
\$ 1,000+[0.35 \times(\$ 4,000-\$ 1,000)] .
$$

The number of shares repurchased would be $51.25(\$ 2,050 / \$ 40)$, so dilution would be only 48.75 shares (versus 75 shares). Obviously, therefore, the effect of taxes on dilution can be large, especially when the options are deep in the money.

Furthermore, the treasury stock method deals only with the intrinsic value of the shares, not with their option value. The issue is most clearly seen in the case of options currently at the money. They are not considered dilutive under current EPS computations because they are not in the money. But in a probabilistic sense, they clearly represent claims against the assets of the company. In the extreme, one can imagine two otherwise identical companies, one with a substantial number of options outstanding that are at the money and one with no options. If the companies perform well, optionholders will exercise and share in the upside potential of the company that has options outstanding, while shareholders will receive all of the benefits in the company with no options. If, in contrast, the companies perform poorly, the optionholders will not exercise and will not share in the downside. Clearly, the existence of the options dilutes the value of earnings to the existing shareholders even if the options are not currently in the money. 
How, then, should options be incorporated in dilution calculations? The answer is based on the likelihood and magnitude of option claims against the company. For companies with options, two sets of claims exist against a company's equity-those of current shareholders and those of optionholders. Regarding dilution, consider how much of an additional dollar of company value belongs to current shareholders.

Start with the following decomposition of equity value:

$$
V=P N_{S}+O N_{o} \text {, }
$$

where $V$ is the total value of equity (including both existing shares and options), $P$ is the price per share, $N_{s}$ is the number of shares, $O$ is the value per option, and $N_{o}$ is the number of options. In other words, the total value of the equity of the company is split between the piece owned by optionholders and the piece owned by the existing shareholders. Taking the derivative of both sides with respect to $V$ :

$$
\frac{d V}{d V}=1=\left(N_{s} \frac{d P}{d V}\right)\left(1+\frac{N_{o}}{N_{s}} \frac{d O}{d P}\right)
$$

Rearranging produces

$$
N_{s} \times \frac{d P}{d V}=\frac{1}{1+\frac{N_{o}}{N_{s}} \frac{d O}{d P}} .
$$

The term on the left-hand side of the equation is the change in market value of shares outstanding per dollar of change in total value of equity. In other words, if the company took an action that increased total equity value by $\$ 1$, the equation captures the proportion of the benefit that accrues to the existing shareholders. Because the term in the denominator on the right-hand side is greater than 1 in the presence of options, shareholders do not capture the entire benefit of changes in equity value.

The term in the denominator of the expression on the right-hand side of the equation, $d O / d P$, represents the change in the value of an option for a small change in the stock price, commonly referred to as the delta of the option. In terms of the Black-Scholes formula, the delta is the term $N(D 1)$ and is a standard output from an option-pricing model. A website, such as www.numa.com, can provide an option calculator that will compute the value of an option along with its delta. 
One can use the information from the option footnote to compute the dilutive effect of each group of outstanding options. For example, consider Dell's 30 million options with a strike price of $\$ 0.96$. Using the same assumptions as those used to value outstanding options at the beginning of this monograph, the average delta for that group of 30 million options is essentially 1. Because those options are so deep in the money, their value moves virtually dollar for dollar with share price. Other option groupings have deltas farther below 1 because they are not as deep in the money. For example, the 49 million options with a strike of $\$ 44.69$ have a delta of 0.63 . Multiplying the number of options in each group by their deltas then summing and dividing by shares outstanding gives the term $\left(N_{o} / N_{s}\right)(d O / d P)=0.1065$, implying that 90.5 percent of all value created accrues to the shareholders and the other 9.5 percent accrues to the optionholders as an increase in the value of their options.

\section{Market Valuation of Options}

Another tool for examining the implications of options for equity valuation is to consider how the market values companies with options. If one assumes market efficiency, inferring the equity valuation implications of options from their association with share price should be possible.

As illustrated in Equation 1.3, options can affect equity valuations in three ways. First, outstanding options create a "liability" or claim against the existing equityholders of the company. As a result (and all other factors being equal), a company's equity should be worth less if it has a substantial quantity of outstanding options. This effect is shown in the adjustment for the expected cost of existing options in Equation 1.3.

Second, outstanding options create a potential asset. Options are designed to provide benefits in terms of incentives and retention. As a result, companies with outstanding options may enjoy improved incentives, even if the options are vested. This effect is shown in the adjustment for the expected incremental operating cash inflows from options in Equation 1.3.

Third, options create an expense as the asset is used up. This effect is indirect, but as with any income statement amount, it provides evidence of the past cost of doing business, which may be indicative of likely future costs. In Equation 1.3, this effect is shown in the adjustment for the expected cost of future options.

Accounting for options, however, does not closely follow this treatment. Most companies do not recognize an expense for options, and even if they do, they recognize no asset or liability. The original exposure draft on SFAS No. 123 proposed an asset, but the final standard only recognizes options as an 
expense as they are earned by employees. Furthermore, companies do not record a liability but rather offset stock option compensation expense with a credit to additional paid-in capital. As a consequence, a portion of equity "belongs" to shareholders and a portion to optionholders. But the equity component is not revalued based on changes in share price or other inputs into the option-pricing model.

The empirical evidence has attempted to detect whether, controlling for other factors, options appear to have an incremental effect on equity valuation. The task is complicated by the fact that many of the companies that have historically issued options are not profitable and have primarily intangible assets. As a result, equity valuation for those companies is particularly difficult. Furthermore, companies that have performed well may reward employees with more options, making it difficult to infer causality based on an observed relationship between performance and option intensity. Finally, the technology bubble in equity valuation creates at least the possibility that past share prices are not good estimates of company value. As a result, companies with options may have traded at particularly high valuations not because options were valued highly but because those companies had other attributes that made them particularly attractive to the market.

Although several articles have been written on the subject, probably the most relevant is Bell, Landsman, Miller, and Yeh (2002), which addresses the market valuation of options for a sample of profitable software companies. This particular sample of companies was chosen because software companies are likely to be option intensive and profitable companies are easier to value. The authors estimated the Black-Scholes value of options outstanding as well as the pro forma option expense and asked whether companies with more options outstanding and more pro forma option expense have lower stock market valuation. They controlled for other assets, liabilities, and net income before the effects of options.

Their study did not differentiate between the option asset and liability (because the two are difficult to disentangle) but simply asked whether the estimated value of outstanding options affects stock price valuation by investors. They also considered the relationship between pro forma option expense and market valuations. Their results provide little evidence that options outstanding are valued as net liabilities of the company. In fact, if anything, they may be net assets (although the effect is small). The implication is that the expected benefit effect of options on future operating cash flows is viewed by the market as offsetting the expected cost of the obligation.

Furthermore, Bell et al. found mixed evidence on the expense component. In the equity valuation regression, companies with larger pro forma option 
expense do not appear to suffer lower market valuations. But in supplementary analysis, the authors found that higher option expense does predict lower future earnings (net of options), all else being equal. It is not clear why the two approaches yield inconsistent results. Perhaps the amortization of options over the vesting period does not accurately spread the costs to the relevant periods. The authors noted that options may create an intangible asset with a longer life than the vesting period. For example, options are generally held after vesting, creating potentially longer-term incentive and retention benefits. Thus, the period over which pro forma option expense is amortized is estimated inaccurately. Ultimately, they concluded that the inconsistency of results may reflect a misspecification of their estimation model or a failure by the market to appreciate the implications of options during their sample period (1996-1998).

Other studies also provide mixed results. For example, Aboody (1996) used pre-SFAS No. 123 data to estimate the equity valuation implications of options. He found a negative association between share prices and options outstanding for a sample of 478 option-intensive companies in 1988, suggesting that options are valued as a liability by the market. Similarly, research by Aboody, Barth, and Kasznik (2002), using a more recent sample of small to medium companies, provides evidence that the market values options as an expense, especially once future earnings growth is controlled for, suggesting that options represent an asset for the company that is used up over the life of the options.

Overall, drawing strong conclusions from the existing research on the stock market valuation of options is difficult. One potential conclusion raised by Bell et al. is that the context is important in assessing the value of options. For example, options may add value for profitable software companies because such companies are relatively stable and intangible assets are especially important. But for a broader sample of companies, the value of options is less clear.

The important point, however, is that, in various instances, options almost certainly represent an asset, a liability, and an expense. In particular, outstanding options appear to represent an obligation to the company and must create some value because they provide incentive and retention effects while also substituting for other forms of compensation. Furthermore, they must ultimately represent an expense because the asset does not have an infinite life. As a consequence, the mixed results probably reflect the difficulty in structuring the analysis. 


\section{Summary and Application}

The discussion in this monograph suggests that options represent a substantial obligation for a company because they create a competing claim on the company's equity. If shares are repurchased to satisfy option exercise, options represent a direct reduction of future cash flows. If shares issued for stock option exercises are not repurchased, existing shareholders suffer dilution of their ownership interest because equity is sold for less than its fair value. In either case, options create a claim against the company that should be considered in equity valuation.

Furthermore, as argued at the beginning of the monograph, a basic approach for incorporating options in equity valuation is not difficult. Perhaps the easiest way to structure the problem is to begin with a basic discounted cash flow analysis and then factor in options explicitly. This approach seems appropriate because past profitability data and earnings forecasts typically exclude the cost of options because options are not expensed under current accounting. Given a discounted cash flow analysis that ignores option costs, options can be explicitly factored in by considering three major components: (1) the obligation for currently outstanding options, (2) the cost of future option grants, and (3) the benefits of option grants.

1. The obligation for currently outstanding options is essentially a liability and is easiest to account for because the options are already outstanding and so less estimation is required. As demonstrated in the Dell example, footnote information on outstanding options can be used to estimate the likely amount and timing of stock option exercise so that it can be built into equity valuation. In particular, a standard option-pricing model, such as the modified Black-Scholes model, can be used to estimate the present value of the option obligation, taking into account the terms of outstanding options. That obligation represents a direct reduction of the value of existing shareholders' claims, much as any other unrecognized liability.

2. The cost of future option grants is like an expense, but it is difficult to factor in because it requires a forecast of future option grants. Once again, as demonstrated by the Dell example, the pro forma option expense in the footnotes is a good starting point because it offers some insight into the cost of options in the past, which should be informative about the likely magnitude of option obligations going forward. Given an assumption about future option intensity (for example, that option grants increase with 
the growth rate of sales), estimating the present value of expected future option-based compensation is not difficult. The cost of future grants represents a reduction in the value of shareholders' ownership in a company and should be incorporated in equity valuation. Furthermore, assuming that options substitute for other compensation, an error in estimating option intensity should be offset by errors in measures of other compensation components.

3. The benefit from option grants is like an asset and is probably the most difficult factor to incorporate in practice. With the obligation side of options, a company controls compensation policy and, therefore, the cost of options granted. Furthermore, the terms of the options clearly indicate the company's obligation. The benefits side is driven primarily by the incentive effects of options, which are difficult to quantify. The underlying rationale for issuing options is based on incentive effects, so the benefits of options cannot be ignored. To the extent that the company has a consistent history of using options in compensation, the incentive effects of options are reflected in past results and so may be captured by forecasting future operating cash flow. For a company that is expected to alter its mix of compensation significantly, the incentive effects are more difficult to calculate because the change could affect employees' willingness to take on risk and work to increase share price.

Finally, the Dell example demonstrates how, under a very simple set of assumptions, estimates of the cost of a company's outstanding and expected future options can be taken into account. Such an approach can be taken as a starting point by using readily available data and a fairly naive set of assumptions to think about the equity valuation consequences of options. As the Dell example illustrates, the effect of stock options on equity valuation can be substantial and needs to be at least considered for an option-intensive company.

\section{Implications of the Research}

After establishing a basic equity valuation model for options, the model can be adjusted according to the evidence found in the research literature. The adjustments suggested by the research are not simple, but the research illustrates the contexts in which the adjustments might be warranted.

Research on option exercise, for example, suggests that, in a given company, exercise tends to be spread out over time rather than occurring at the average life of options, as assumed in the modified Black-Scholes model. As a result, an option-valuation approach that smoothes exercise over time as opposed to assuming that exercise occurs all at once may be merited. Such an approach is easy to implement. Simply spread the options into subsets 
assumed to be exercised at various times around the average exercise period and value each subset separately. For example, the Dell calculation assumes $1 / 18$ th of the options were exercised in each of the six-month periods centered on the end of Year 5.

Similarly, option exercise is likely to be elevated in certain contexts. For example, options that are deeper in the money, more volatile, more likely to be canceled, closer to expiration, or held by lower-level employees are likely to be exercised sooner. As a result, an approach that explicitly takes into account the characteristics of existing options is more likely to accurately reflect the effects of options.

Closely related, the option literature points out a number of other ways that traditional option-valuation approaches developed for traded options might be misspecified. For example, exercise may be clustered among subsets of options with certain characteristics (such as deeper-in-the-money options closer to expiration), thus contradicting the implicit assumptions underlying the modified Black-Scholes model.

Although such issues are important in theory, and option-pricing models can be adjusted to account for alternate exercise patterns, empirical evidence suggests that the amount of bias introduced by ignoring exercise patterns in practice tends to be fairly modest. Although the modified Black-Scholes model has been criticized for incorporating unrealistic assumptions, it seems to perform relatively well at valuing employee stock options in practice.

Of greater potential importance are the assumptions-such as the riskfree rate, volatility, dividend policy, and expected life-that go into the computation of option value. Although the footnote disclosure provides a useful starting point for assessing option value and research to date provides little evidence that assumptions are manipulated, option values are sensitive to the underlying assumptions and care should be taken to ensure that they are reasonable and comparable across companies.

Even beyond their direct equity valuation implications, considering the cash flow effect of options on managerial decision making is important. For example, an option-intensive company that has a policy of repurchasing shares to satisfy option exercise is likely to have significant cash flow needs, especially if share price has appreciated significantly. Although the decision to repurchase shares may not have direct equity valuation implications, it is important to determine how the necessary cash to repurchase shares is likely to be raised, especially if it might come at the expense of operating activities or change the company's financing structure.

Similarly, the tax consequences of options should be considered. The tax effects of NQOs can be substantial and are difficult to disentangle under 
current accounting for stock options. Furthermore, the tax benefits resulting from the exercise of NQOs can have significant implications for a company's future cash flows, and option tax deductions can significantly reduce the aftertax cost of options. But many option-intensive companies may face limits on their ability to immediately benefit from option deductions because their taxable income may be well below that implied by net income on their financial statements. As a consequence, explicitly building in assumptions about the tax consequences of outstanding and expected future options is important in assessing cash flows and company value.

Options also have implications for the dilution of earnings. Although an attempt is made to account for options in computing diluted EPS for financial statements, the treasury stock method used under current accounting ignores at least two important features of options. First, option exercise typically creates significant tax benefits, which are ignored under the treasury stock method of computing diluted EPS, even though adjusting diluted EPS for the tax effects of option exercise is a straightforward process. Second, standard diluted EPS calculations focus on the intrinsic value of options and ignore the option component, especially for options that are not currently in the money but that represent claims against the company's earnings. Using standard option-pricing approaches, one can compute the proportion of an additional dollar of earnings that is implicitly spoken for by outstanding options and, hence, the proportion that remains for the existing shareholders.

The research has less to say about the benefits of employee option plans, especially in the case of lower-level employees. It does, however, suggest that options are a relatively expensive form of compensation because they impose risk on the employee, which necessitates higher expected compensation. Because of risk aversion, employees may perceive a value of options that is substantially below their cost to the company. Although that deadweight cost may be justified because of the incentive benefits, the research evidence on incentive effects of broad-based option plans is mixed. At a minimum, a change in compensation mix can affect total compensation to the extent that employees do not value options as highly as other forms of compensation.

Even for higher-level employees, the research evidence linking options and performance is mixed, perhaps because of the difficulty of measuring the relationship. And although research evidence suggests that including options in compensation agreements may affect employees' willingness to take on risk, options may either increase or decrease employees' risk tolerances depending on the specific context. In fact, options may create incentives to artificially deflate share price prior to option grants or inflate share price before option exercises to maximize the spread between the market and strike prices. 
Research on the market valuation effects of options in practice is also mixed. Although the presence of options should affect the amount investors are willing to pay for shares, options have a variety of potential effects on share price. For example, outstanding options create both potential assets and liabilities for the company. Similarly, options represent an expense of doing business, which should reduce share price. But designing tests to detect such effects is difficult in practice because option-granting companies tend to be difficult to value and the causal links between options and performance are complex. Although some evidence indicates that options are reflected in share prices, the results differ depending on the specific context.

\section{Future Option Issues}

Finally, research provides some insight into the current proposals by the International Accounting Standards Board (IASB) and the Financial Accounting Standards Board (FASB) to mandate option expense recognition in the near future. First, the proposals would have little effect on the approach for incorporating options into equity valuation. In particular, the FASB's proposal would simply move the pro forma expense data from the option footnote to the face of the income statement but would not significantly change the total set of information available to value the company because the current footnote information would still be required. As a result, consideration of the cost of outstanding and future options, as well as the benefits of options, would still be necessary. Perhaps the most substantive effect would be a change in the earnings number forecasted by analysts. For example, if options are expensed and analysts continue to forecast reported earnings, they will need to incorporate future option costs to determine compensation expense. As a consequence, future option costs will already be included in earnings forecasts and will not need to be incorporated separately in equity valuation, but adjusting equity valuations for the cost of outstanding options will still be necessary.

Second, research and casual observation suggest that accounting changes could have significant influence on option intensity in compensation design. In large part, likely changes hinge on the extent to which current option pervasiveness reflects favorable accounting treatment. For example, Hall and Murphy (2003) argued that the popularity of option compensation is most consistent with a desire to achieve favorable accounting treatment. Were the accounting treatment to change, the attractiveness of options could change as well. Certainly, the evidence on repricing suggests that managers are willing to change compensation structure in response to accounting changes.

Assuming the IASB and the FASB require options to be expensed, a primary motivation for issuing options with current characteristics, such as 
issued at the money with preset terms, will likely disappear. With the accounting benefit gone, one might expect to see a shift from options to other forms of compensation, especially in broad-based option plans, because it is difficult to justify option-based compensation for employees who are more risk averse and have less control over stock price. Although those options may be replaced by other compensation, the trade-off may be less than one for one because employees are likely to accept a lower expected value of total compensation in exchange for lower risk.

\section{Possible Shift to Restricted Stock}

Some evidence indicates that such companies as Microsoft and Dell are shifting from stock options to restricted stock in anticipation of the accounting change. Conceptually, restricted stock is like an option issued with a strike of zero. Because it does not require payment of a strike price, a share of restricted stock is worth substantially more at grant than an option issued at the money, and therefore, a company could substitute fewer shares of restricted stock for a given number of options.

From an employee's perspective, a given value of restricted stock is less risky than a comparable amount of stock options because, as a percentage of its value, the restricted stock is less sensitive to movements in share price. As a result, substituting restricted stock for stock options will tend to reduce total compensation cost to the company. But the trade-off is that the sensitivity to share price provides the incentive effect. Restricted stock offers employees less risk than typical stock options but also less upside potential and thus, possibly, less incentive to build value in the company.

To the extent companies continue to use options, their terms will likely change if options are expensed. For example, companies avoid expensing options under current accounting if they are granted at the money with fixed terms. Were the rules changed, one might expect to see more performancebased options (which pay out only if certain performance goals are achieved or measure performance relative to a benchmark, such as industry performance) and more options with lower strike prices (such as restricted stock). Even if the accounting changes, however, options are likely to have significant equity valuation implications for the foreseeable future. 


\section{Appendix: Selected Disclosures from Dell Computer's 2002 Annual Report}

\section{Dell Computer Corporation}

\section{Consolidated Statement of Financial Position (in millions)}

\begin{tabular}{|c|c|c|}
\hline & February 1,2002 & February 2, 2001 \\
\hline \multicolumn{3}{|l|}{ ASSETS } \\
\hline \multicolumn{3}{|l|}{ Current assets } \\
\hline Cash and cash equivalents & $\$ 3,641$ & $\$ 4,910$ \\
\hline Short-term investments & 273 & 525 \\
\hline Accounts receivable, net & 2,269 & 2,424 \\
\hline Inventories & 278 & 400 \\
\hline Other & $\underline{1,416}$ & $\underline{1,467}$ \\
\hline Total current assets & $\overline{7,877}$ & $\overline{9,726}$ \\
\hline Property, plant, and equipment, net & 826 & 996 \\
\hline Investments & 4,373 & 2,418 \\
\hline Other noncurrent assets & 459 & $\underline{530}$ \\
\hline Total assets & $\$ 13, \overline{535}$ & $\$ 13, \overline{670}$ \\
\hline \multicolumn{3}{|c|}{ LIABILITIES AND STOCKHOLDERS EQUITY } \\
\hline \multicolumn{3}{|l|}{ Current liabilities } \\
\hline Accounts payable & $\$ 5,075$ & $\$ 4,286$ \\
\hline Accrued and other & 2,444 & $\underline{2,492}$ \\
\hline Total current liabilities & $\overline{7,519}$ & 6,778 \\
\hline Long-term debt & 520 & 509 \\
\hline Other & 802 & 761 \\
\hline Other commitments and contingent liabilities (Note 7) & $=$ & $=$ \\
\hline Total liabilities & $8,8 \overline{41}$ & $8,0 \overline{48}$ \\
\hline \multicolumn{3}{|l|}{ Stockholders equity } \\
\hline $\begin{array}{l}\text { Preferred stock and capital in excess of } \$ 0.01 \text { par value; } \\
\text { shares issued and outstanding: none }\end{array}$ & - & - \\
\hline $\begin{array}{l}\text { Common stock and capital in excess of } \$ 0.01 \text { par value; shares } \\
\text { authorized: } 7,000 \text {; shares issued: } 2,654 \text { and } 2,601 \text {, respectively }\end{array}$ & 5,605 & 4,795 \\
\hline Treasury stock, at cost; 52 shares and no shares, respectively & $(2,249)$ & - \\
\hline Retained earnings & 1,364 & 839 \\
\hline Other comprehensive income & 38 & 62 \\
\hline Other & $\underline{(64)}$ & $\underline{(74)}$ \\
\hline Total stockholders equity & $\underline{4,694}$ & $\underline{5,622}$ \\
\hline Total liabilities and stockholders equity & $\$ 13,535$ & $\$ 1 \overline{13,670}$ \\
\hline
\end{tabular}




\section{Dell Computer Corporation}

Consolidated Statement of Income (in millions, except per share amounts)

\begin{tabular}{|c|c|c|c|}
\hline \multirow[b]{3}{*}{ Net revenue } & \multicolumn{3}{|c|}{ Fiscal Year Ended } \\
\hline & February 1, 2002 & February 2, 2001 & January 28,2000 \\
\hline & $\$ 31,168$ & $\$ 31,888$ & $\$ 25,265$ \\
\hline Cost of revenue & 25,661 & 25,445 & 20,047 \\
\hline Gross margin & 5,507 & 6,443 & 5,218 \\
\hline \multicolumn{4}{|l|}{ Operating expenses } \\
\hline Selling, general, and administrative & 2,784 & 3,193 & 2,387 \\
\hline $\begin{array}{l}\text { Research, development, and } \\
\text { engineering }\end{array}$ & 452 & 482 & 374 \\
\hline Special charges & 482 & 105 & 194 \\
\hline Total operating expenses & $\underline{3, \overline{718}}$ & $\underline{3, \overline{780}}$ & $2 \overline{2,955}$ \\
\hline Operating income & 1,789 & 2,663 & 2,263 \\
\hline $\begin{array}{l}\text { Investment and other income (loss), } \\
\text { net }\end{array}$ & (58) & 531 & 188 \\
\hline $\begin{array}{l}\text { Income before income taxes and } \\
\text { cumulative effect of change in } \\
\text { accounting principle }\end{array}$ & 1,731 & 3,194 & 2,451 \\
\hline Provision for income taxes & $\underline{485}$ & $\underline{958}$ & $\underline{785}$ \\
\hline $\begin{array}{l}\text { Income before cumulative effect of } \\
\text { change in accounting principle }\end{array}$ & 1,246 & 2,236 & 1,666 \\
\hline $\begin{array}{l}\text { Cumulative effect of change in } \\
\text { accounting principle, net }\end{array}$ & - & $\underline{59}$ & - \\
\hline Net income & $\underline{\$ 1,246}$ & $\$ 2,1 \overline{77}$ & $\$ 1,666$ \\
\hline \multicolumn{4}{|l|}{$\begin{array}{l}\text { Earnings per common share: before } \\
\text { cumulative effect of change in } \\
\text { accounting principle }\end{array}$} \\
\hline Basic & $\$ 0.48$ & $\$ 0.87$ & $\$ 0.66$ \\
\hline Diluted & $\$ 0.46$ & $\$ 0.81$ & $\$ 0.61$ \\
\hline \multicolumn{4}{|l|}{$\begin{array}{l}\text { After cumulative effect of change in } \\
\text { accounting principle }\end{array}$} \\
\hline Basic & $\$ 0.48$ & $\$ 0.84$ & $\$ 0.66$ \\
\hline Diluted & $\$ 0.46$ & $\$ 0.79$ & $\$ 0.61$ \\
\hline \multicolumn{4}{|l|}{ Weighted-average shares outstanding } \\
\hline Basic & 2,602 & 2,582 & 2,536 \\
\hline Diluted & 2,726 & 2,746 & 2,728 \\
\hline
\end{tabular}




\section{Dell Computer Corporation}

\section{Consolidated Statement of Cash Flows (in millions)}

\begin{tabular}{|c|c|c|c|}
\hline \multirow{2}{*}{ Cash flows from operating activities } & \multicolumn{3}{|c|}{ Fiscal Year Ended } \\
\hline & February 1,2002 & February 2, 2001 & January 28,2000 \\
\hline \multicolumn{4}{|l|}{$\begin{array}{l}\text { Adjustments to reconcile net income to net } \\
\text { cash provided by operating activities }\end{array}$} \\
\hline Depreciation and amortization & 239 & 240 & 156 \\
\hline Tax benefits of employee stock plans & 487 & 929 & 1,040 \\
\hline Special charges & 742 & 105 & 194 \\
\hline (Gains)/losses on investments & 17 & (307) & (80) \\
\hline Other & 178 & 135 & 56 \\
\hline \multicolumn{4}{|l|}{ Changes in } \\
\hline Operating working capital & 826 & 642 & 812 \\
\hline Noncurrent assets and liabilities & $\underline{62}$ & $\underline{274}$ & $\underline{82}$ \\
\hline Net cash provided by operating activities & $\underline{3,7 \overline{97}}$ & $\underline{4,195}$ & $\underline{3,926}$ \\
\hline \multicolumn{4}{|l|}{$\begin{array}{l}\text { Cash flows from investing activities } \\
\text { Investments }\end{array}$} \\
\hline Purchases & $(5,382)$ & $(2,606)$ & $(3,101)$ \\
\hline Maturities and sales & 3,425 & 2,331 & 2,319 \\
\hline Capital expenditures & $\underline{(303)}$ & $\underline{(482)}$ & $\underline{(401)}$ \\
\hline Net cash used in investing activities & $(2,260)$ & $\underline{(757)}$ & $(1,183)$ \\
\hline \multicolumn{4}{|l|}{ Cash flows from financing activities } \\
\hline $\begin{array}{l}\text { Purchase of common stock } \\
\text { Issuance of common stock under }\end{array}$ & $(3,000)$ & $(2,100)$ & $(1,061)$ \\
\hline employee plans & 295 & 404 & 289 \\
\hline Other & $\underline{3}$ & (9) & $\underline{77}$ \\
\hline Net cash used in financing activities & $(2,702)$ & $(2,305)$ & $(\overline{695})$ \\
\hline Effect of exchange rate changes on cash & $\underline{(104)}$ & (32) & $\underline{35}$ \\
\hline Net (decrease)/increase in cash & $(1,269)$ & 1,101 & 2,083 \\
\hline \multicolumn{3}{|l|}{ Cash and cash equivalents at beginning of } & $\underline{1,726}$ \\
\hline Cash and cash equivalents at end of period & $\$ \overline{3,641}$ & $\$ \overline{4,910}$ & $\$ \overline{3,809}$ \\
\hline \multicolumn{4}{|c|}{ SUPPLEMENTAL CONSOLIDATED FINANCIAL INFORMATION } \\
\hline Income taxes paid/(received) & $\$ 120$ & $(\$ 32)$ & $(\$ 363)$ \\
\hline Interest paid & $\$ 31$ & $\$ 49$ & $\$ 34$ \\
\hline
\end{tabular}


Dell Computer Corporation

Consolidated Statement of Stockholders Equity (in millions)

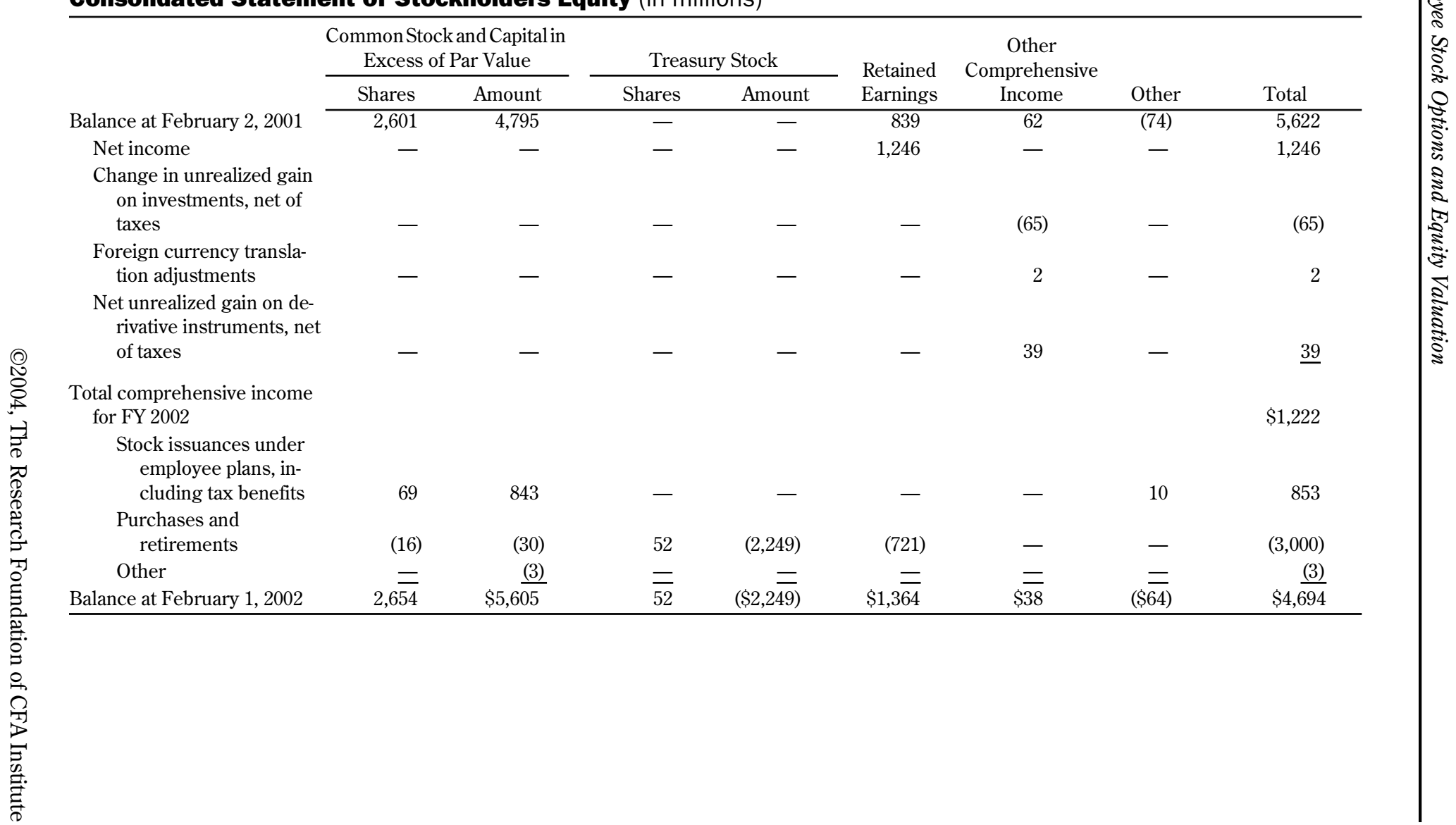




\section{Dell Computer Corporation}

\section{Selected Footnotes}

Earnings Per Common Share: Basic earnings per share is based on the weighted effect of all common shares issued and outstanding and is calculated by dividing net income by the weighted-average shares outstanding during the period. Diluted earnings per share is calculated by dividing net income by the weighted-average number of common shares used in the basic earnings per share calculation plus the number of common shares that would be issued assuming exercise or conversion of all potentially dilutive common shares outstanding. The following table sets forth the computation of basic and diluted earnings per share for each of the past three fiscal years:

(in millions, except per share amounts)

\begin{tabular}{|c|c|c|c|}
\hline & \multicolumn{3}{|c|}{ Fiscal Year Ended } \\
\hline & February 1, 2002 & February 2, 2001 & January 28,2000 \\
\hline Net income & $\$ 1,246$ & $\$ 2,177$ & $\$ 1,666$ \\
\hline \multicolumn{4}{|l|}{ Weighted-average shares outstanding } \\
\hline Basic & 2,602 & 2,582 & 2,536 \\
\hline Employee stock options and other & $\underline{124}$ & $\underline{164}$ & $\underline{192}$ \\
\hline Diluted & $\underline{2,726}$ & $\underline{2,746}$ & $\underline{2,728}$ \\
\hline \multicolumn{4}{|l|}{ Earnings per common share } \\
\hline \multicolumn{4}{|l|}{$\begin{array}{l}\text { Before cumulative effect of change } \\
\text { in accounting principle }\end{array}$} \\
\hline Basic & $\$ 0.48$ & $\$ 0.87$ & $\$ 0.66$ \\
\hline Diluted & $\$ 0.46$ & $\$ 0.81$ & $\$ 0.61$ \\
\hline \multicolumn{4}{|l|}{$\begin{array}{l}\text { After cumulative effect of change in } \\
\text { accounting principle }\end{array}$} \\
\hline Basic & $\$ 0.48$ & $\$ 0.84$ & $\$ 0.66$ \\
\hline Diluted & $\$ 0.46$ & $\$ 0.79$ & $\$ 0.61$ \\
\hline
\end{tabular}

\section{Note 6. Benefit Plans}

Stock option plans: The Compensation Committee of the Board of Directors administers the Company's two stock option plans, the Dell Computer Corporation Incentive Plan (the Incentive Plan) and the Dell Computer Corporation 1998 Broad-Based Stock Option Plan (the Broad-Based Plan and, together with the Incentive Plan, the Option Plans). The Incentive Plan provides for the granting of stock-based incentive awards to the Company's directors (including the nonemployee directors), executive officers, and key employees and to certain of its consultants and advisors; the Broad-Based Plan provides for the award of stock options to non-executive employees. 
Options granted under the Incentive Plan may be either incentive stock options within the meaning of Section 422 of the Internal Revenue Code or nonqualified; only nonqualified stock options can be granted under the BroadBased Plan. Under either of the Option Plans, the right to purchase shares pursuant to existing stock option agreements typically vest pro rata at each option anniversary date over a five-year period. The options are generally issued at fair market value and must be exercised within 10 years from the date of grant.

The following table summarizes stock option activity for the option plans (share data in millions).

\begin{tabular}{|c|c|c|c|c|c|c|}
\hline & \multicolumn{6}{|c|}{ Fiscal Year Ended } \\
\hline & \multicolumn{2}{|c|}{ February 1, 2002} & \multicolumn{2}{|c|}{ February 2, 2001} & \multicolumn{2}{|c|}{ January 28,2000} \\
\hline & $\begin{array}{c}\text { No. of } \\
\text { Options }\end{array}$ & $\begin{array}{c}\text { Weighted- } \\
\text { Average } \\
\text { Exercise Price }\end{array}$ & $\begin{array}{l}\text { No. of } \\
\text { Options }\end{array}$ & $\begin{array}{c}\text { Weighted- } \\
\text { Average } \\
\text { Exercise Price }\end{array}$ & $\begin{array}{l}\text { No. of } \\
\text { Options }\end{array}$ & $\begin{array}{c}\text { Weighted- } \\
\text { Average } \\
\text { Exercise Price }\end{array}$ \\
\hline $\begin{array}{l}\text { Options outstanding } \\
\text { beginning of year }\end{array}$ & 344 & $\$ 24.36$ & 320 & $\$ 11.39$ & 363 & $\$ 5.40$ \\
\hline Granted & 126 & 23.24 & 154 & 37.78 & 50 & 42.86 \\
\hline Exercised & (63) & 3.11 & (95) & 3.26 & (77) & 2.48 \\
\hline Canceled & (57) & 32.86 & $\underline{(35)}$ & 22.18 & (16) & 9.89 \\
\hline $\begin{array}{l}\text { Options outstanding } \\
\text { end of year }\end{array}$ & 350 & 26.36 & 344 & 24.36 & 320 & 11.39 \\
\hline $\begin{array}{l}\text { Options exercisable end } \\
\text { of year }\end{array}$ & 98 & $\$ 17.49$ & 100 & $\$ 8.78$ & 112 & $\$ 3.96$ \\
\hline
\end{tabular}

The following is additional information relating to options for the option plans outstanding as of February 1, 2002.

\begin{tabular}{|c|c|c|c|c|c|}
\hline & \multicolumn{3}{|c|}{ Options Outstanding } & \multicolumn{2}{|c|}{ Options Exercisable } \\
\hline & $\begin{array}{l}\text { No. of } \\
\text { Shares }\end{array}$ & $\begin{array}{c}\text { Weighted- } \\
\text { Average Exercise } \\
\text { Price }\end{array}$ & $\begin{array}{l}\text { Weighted-Average } \\
\text { Remaining } \\
\text { Contractual Life } \\
\text { (years) }\end{array}$ & $\begin{array}{l}\text { No. of } \\
\text { Shares }\end{array}$ & $\begin{array}{c}\text { Average Exercise } \\
\text { Price }\end{array}$ \\
\hline$\$ 0.01-\$ 1.49$ & 30 & $\$ 0.96$ & 3.49 & 30 & $\$ 0.98$ \\
\hline$\$ 1.50-\$ 14.99$ & 38 & 7.34 & 5.34 & 28 & 7.13 \\
\hline$\$ 15.00-\$ 22.49$ & 53 & 21.35 & 9.12 & 3 & 17.35 \\
\hline$\$ 22.50-\$ 24.00$ & 41 & 22.94 & 9.02 & - & 23.42 \\
\hline$\$ 24.01-\$ 35.99$ & 53 & 26.99 & 8.30 & 12 & 30.07 \\
\hline$\$ 36.00-\$ 37.59$ & 86 & 37.59 & 8.54 & 9 & 37.58 \\
\hline$\$ 37.60-\$ 57.82$ & $\underline{49}$ & $\$ 44.69$ & 7.89 & $\underline{16}$ & $\$ 44.85$ \\
\hline & 350 & & & 98 & \\
\hline
\end{tabular}


There were 290 million, 254 million, and 264 million options to purchase the Company's common stock available for future grants under the Option Plans at February 1, 2002, February 2, 2001, and January 28, 2000, respectively.

Fair Value Disclosures: The weighted-average fair value of stock options at date of grant was $\$ 13.04, \$ 20.98$, and $\$ 22.64$ per option for options granted during fiscal 2002, 2001, and 2000, respectively. Additionally, the weightedaverage fair value of the purchase rights under the employee stock purchase plan granted in fiscal 2002, 2001, and 2000 was $\$ 6.74$, $\$ 13.95$, and $\$ 11.12$ per right, respectively. The weighted-average fair value of options and purchase rights under the employee stock purchase plan was determined based on the Black-Scholes model, using the following assumptions.

\begin{tabular}{lccc}
\hline & \multicolumn{3}{c}{ Fiscal Year Ended } \\
\cline { 2 - 4 } & February 1,2002 & February 2, 2001 & January 28, 2000 \\
\hline Expected term & 5 Years & 5 Years & 5 Years \\
Stock options & 6 Months & 6 Months & 6 Months \\
Employee stock purchase plan & $4.63 \%$ & $6.15 \%$ & $5.81 \%$ \\
Risk-free interest rate & $61.18 \%$ & $54.85 \%$ & $51.03 \%$ \\
Volatility & $0 \%$ & $0 \%$ & $0 \%$ \\
Dividends & &
\end{tabular}

Had the Company accounted for its option plans and employee stock purchase plan by recording compensation expense based on the fair value at the grant date on a straight-line basis over the vesting period, stock-based compensation costs would have reduced pretax income by $\$ 964$ million (\$694 million, net of taxes), $\$ 620$ million ( $\$ 434$ million, net of taxes), and $\$ 329$ million ( $\$ 224$ million, net of taxes) in fiscal 2002, 2001, and 2000, respectively. The pro forma effect on basic earnings per common share would have been a reduction of $\$ 0.27$, $\$ 0.17$, and $\$ 0.09$ for fiscal 2002, 2001, and 2000, respectively. The pro forma effect on diluted earnings per common share would have been a reduction of $\$ 0.27, \$ 0.16$, and $\$ 0.08$ for fiscal 2002,2001 , and 2000 , respectively. 


\section{References}

Aboody, David. 1996. "Market Valuation of Employee Stock Options.” Journal of Accounting and Economics, vol. 22, nos. 1-3 (August-December):357-391.

Aboody, David, and Ron Kasznik. 2000. "CEO Stock Option Awards and the Timing of Corporate Voluntary Disclosures.” Journal of Accounting and Economics, vol. 29, no. 1 (February):73-100.

Aboody, David, Mary Barth, and Ron Kasznik. 2002. "SFAS 123 Stock-Based Compensation and Equity Market Value." Working paper, University of California at Los Angeles, Stanford University.

. 2003. "Do Firms Manage Stock-Based Compensation Expense Disclosed under SFAS 123?" Working paper, University of California at Los Angeles, Stanford University.

Acharya, Viral, Kose John, and Rangarajan K. Sundaram. 2000. “On the Optimality of Resetting Executive Stock Options.” Journal of Financial Economics, vol. 57, no. 1 (July):65-101.

Bell, Timothy, Wayne R. Landsman, Bruce L. Miller, and Shu Yeh. 2002. "The Valuation Implications of Employee Stock Option Accounting for Profitable Computer Software Firms.” Accounting Review, vol. 77, no. 4 (October):971-996.

Bens, Daniel, Venky Nagar, and M.H. Franco Wong. 2002. "Real Investment Implications of Employee Stock Option Exercises." Journal of Accounting Research, vol. 40, no. 2 (May):359-393.

Black, F., and M. Scholes. 1973. "The Pricing of Options and Corporate Securities." Journal of Political Economy, vol. 81, no. 3 (May/June):637-654.

Carpenter, Jennifer. 1998. "The Exercise and Valuation of Executive Stock Options.” Journal of Financial Economics, vol. 48, no. 2 (May):127-158.

Carter, Mary Ellen, and Luann J. Lynch. 2003. "The Consequences of the FASB's 1998 Proposal on Accounting for Stock Option Repricing." Journal of Accounting and Economics, vol. 35, no. 1 (April):51-72.

Core, John, and Wayne Guay. 2001. "Stock Option Plans for Non-Executive Employees.” Journal of Financial Economics, vol. 61, no. 2 (August):253-287.

Core, John, Robert Holthausen, and David Larcker. 1999. "Corporate Governance, CEO Compensation and Firm Performance." Journal of Financial Economics, vol. 51, no. 3 (March):371-406.

Erickson, Merle, Michelle Hanlon, and Edward Maydew. 2003. "Is There a Link between Executive Compensation and Accounting Fraud?" Working paper, University of Chicago, University of Michigan, and University of North Carolina.

Graham, John, Mark Lang, and Doug Shackelford. Forthcoming 2004. "Employee Stock Options, Corporate Taxes, and Debt Policy.” Journal of Finance. 
Hall, Brian, and Kevin J. Murphy. 2002. "Stock Options for Undiversified Executives." Journal of Accounting and Economics, vol. 33, no. 1 (February):3-42.

- 2003. "The Trouble with Stock Options." Journal of Economic Perspectives, vol. 17, no. 3 (Summer):49-72.

Hanlon, Michelle, and Terry Shevlin. 2002. "Accounting for Tax Benefits of Employee Stock Options and Implications for Research.” Accounting Horizons, vol. 16, no. 1 (March):1-16.

Hanlon, Michelle, Shivaram Rajgopal, and Terry Shevlin. 2003. "Are Executive Stock Options Associated with Future Earnings?” Journal of Accounting and Economics, vol. 36, nos. 1-3 (December):3-43.

Heath, C., S. Huddart, and M. Lang. 1999. "Psychological Factors and Stock Option Exercise.” Quarterly Journal of Economics, vol. 114, no. 2 (May):601-628.

Hemmer, Thomas, Steve Matsunaga, and Terry Shevlin. 1994. "Estimating the 'Fair Value' of Employee Stock Options with Expected Early Exercise.” Accounting Horizons, vol. 8, no. 4 (December):23-42.

. 1996. "The Influence of Risk Diversification on the Early Exercise of Employee Stock Options by Executive Officers." Journal of Accounting and Economics, vol. 21, no. 1 (February):45-68.

Holmstrom, B. 1979. "Moral Hazard and Observability." Bell Journal of Economics, vol. 10, no. 1 (Spring):74-91.

Huddart, Steven. 1994. "Employee Stock Options.” Journal of Accounting and Economics, vol. 18, no. 2 (September):207-231.

Huddart, Steven, and Mark Lang. 1996. "Employee Stock Option Exercises: An Empirical Analysis.” Journal of Accounting and Economics, vol. 21, no. 1 (February):5-43.

- 2003. "Information Distribution within Firms: Evidence from Stock Option Exercises.” Journal of Accounting and Economics, vol. 34, nos. 1-3 (January):3-31.

Hull, John C. 2002. Options, Futures, and Other Derivatives. 5th ed. Upper Saddle River, NJ: Prentice Hall.

Ittner, Christopher, Richard A. Lambert, and David F. Larcker. 2003. "The Structure and Performance Consequences of Equity Grants to Employees of New Economy Firms.” Journal of Accounting and Economics, vol. 34, no. 1 (January):89-127.

Kulatilaka, Nalin, and Alan J. Marcus. 1994. "Valuing Employee Stock Options." Financial Analysts Journal, vol. 50, no. 6 (November/December):46-56.

Lambert, R.A., W.N. Lanen, and D.F. Larcker. 1989. "Executive Stock Option Plans and Corporate Dividend Policy.” Journal of Financial and Quantitative Analysis, vol. 24, no. 4 (December):409-425.

Marquardt, Carol. 2002. "The Cost of Employee Stock Option Grants: An Empirical Analysis.” Journal of Accounting Research, vol. 40, no. 4 (September):1191-1217. 
Merton, R. 1973. "Theory of Rational Option Pricing." Bell Journal of Economics and Management Science, vol. 4, no. 1 (Spring):141-183.

Meulbroek, L.K. 2001. "The Efficiency of Equity-Linked Compensation: Understanding the Full Cost of Awarding Executive Stock Options." Financial Management, vol. 30, no. 2 (Summer): 5-30.

Murphy, Kevin J. 2003. "Stock-Based Pay in New Economy Firms." Journal of Accounting and Economics, vol. 34, nos. 1-3 (January):129-147.

Rajgopal, Shivaram, and Terry Shevlin. 2002. "Empirical Evidence on the Relation between Stock Option Compensation and Risk Taking." Journal of Accounting and Economics, vol. 33, no. 2 (June):145-171.

Soffer, Leonard. 2000. "SFAS No. 123 Disclosures and Discounted Cash Flow Valuation.” Accounting Horizons, vol. 14, no. 2 (June):169-189.

Sullivan, M. 2002. "Stock Options Take $\$ 50$ Billion Bite out of Corporate Taxes.” Tax Notes (March):1396-1401. 